Review

\title{
Rational Drug Design and Synthesis of Molecules Targeting the Angiotensin II Type 1 and Type 2 Receptors
}

\author{
Tahsin F. Kellici ${ }^{1,2}$, Andreas G. Tzakos ${ }^{2}$ and Thomas Mavromoustakos ${ }^{1, *}$ \\ 1 Department of Chemistry, National and Kapodistrian University of Athens, \\ Panepistimiopolis Zografou 15771, Greece \\ 2 Department of Chemistry, University of Ioannina, Ioannina 45110, Greece \\ * Author to whom correspondence should be addressed; E-Mail: tmavrom@chem.uoa.gr; \\ Tel.: +30-210-7274475; Fax: +30-210-7274761.
}

Academic Editor: Panayiotis Koutentis

Received: 18 December 2014 / Accepted: 15 February 2015 / Published: 2 March 2015

\begin{abstract}
The angiotensin II (Ang II) type 1 and type 2 receptors $\left(\mathrm{AT}_{1} \mathrm{R}\right.$ and $\mathrm{AT}_{2} \mathrm{R}$ ) orchestrate an array of biological processes that regulate human health. Aberrant function of these receptors triggers pathophysiological responses that can ultimately lead to death. Therefore, it is important to design and synthesize compounds that affect beneficially these two receptors. Cardiovascular disease, which is attributed to the overactivation of the vasoactive peptide hormone Ang II, can now be treated with commercial $\mathrm{AT}_{1} \mathrm{R}$ antagonists. Herein, recent achievements in rational drug design and synthesis of molecules acting on the two AT receptors are reviewed. Quantitative structure activity relationships (QSAR) and molecular modeling on the two receptors aim to assist the search for new active compounds. As $\mathrm{AT}_{1} \mathrm{R}$ and $\mathrm{AT}_{2} \mathrm{R}$ are GPCRs and drug action is localized in the transmembrane region the role of membrane bilayers is exploited. The future perspectives in this field are outlined. Tremendous progress in the field is expected if the two receptors are crystallized, as this will assist the structure based screening of the chemical space and lead to new potent therapeutic agents in cardiovascular and other diseases.
\end{abstract}

Keywords: angiotensin II receptors; $\mathrm{AT}_{1} \mathrm{R} ; \mathrm{AT}_{2} \mathrm{R}$; rational drug design; synthesis; molecular modeling; drug-membrane interactions 


\section{Introduction}

The renin angiotensin system (RAS) is the main target for regulating the body's blood pressure [1]. This is a bioenzymatic system where angiotensinogen, through the two enzymes renin and angiotensin converting enzyme (ACE), is converted to the octapeptide hormone angiotensin II (Ang II) that in pathological conditions causes vasoconstriction. ACE inhibitors were the first drugs designed and synthesized to block the detrimental effects of Ang II (a compound word of Greek origin composed of

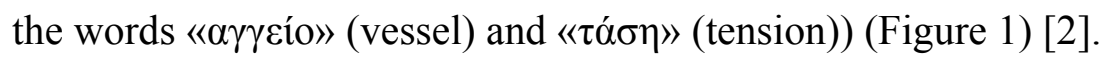

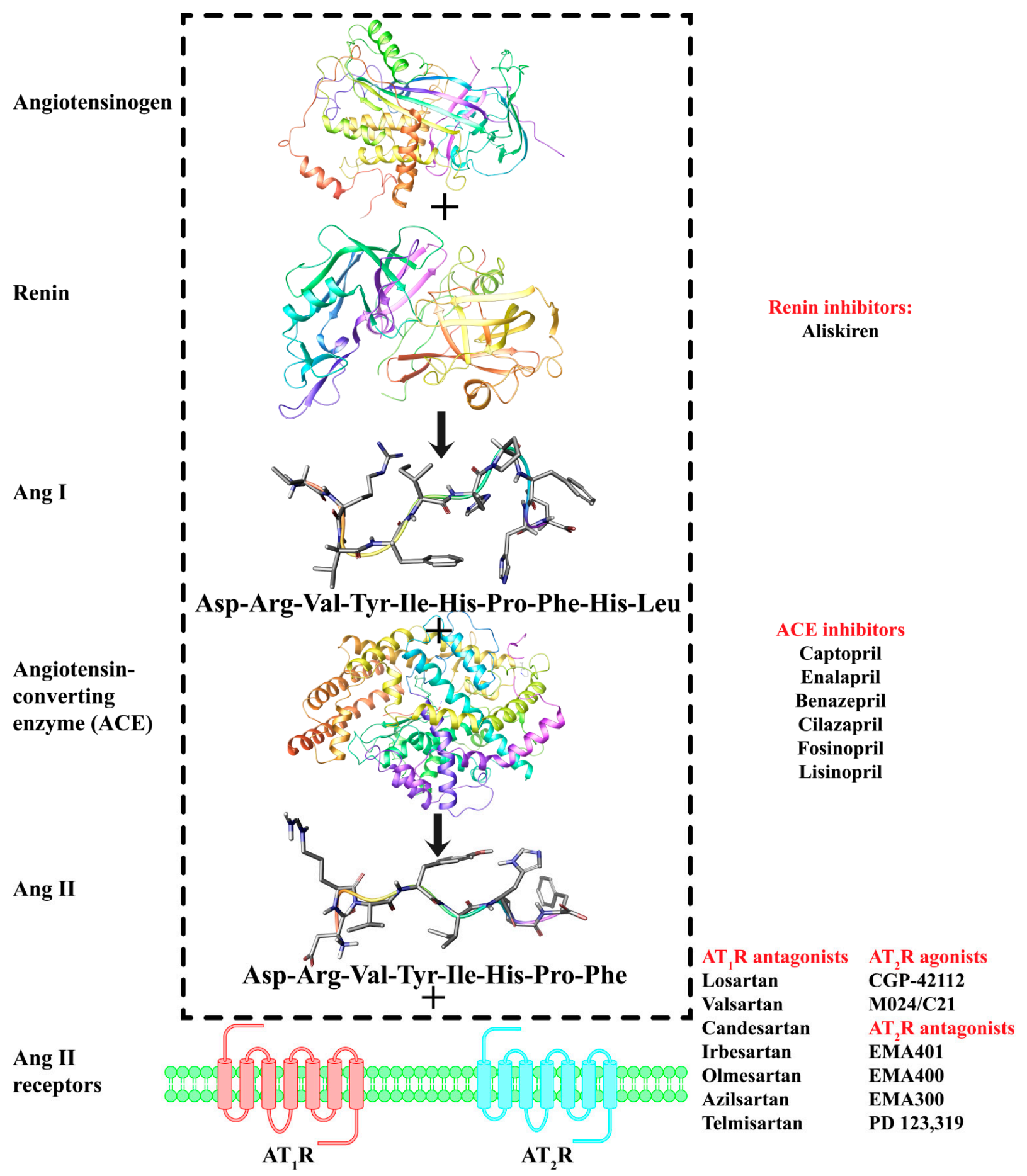

Figure 1. The RAS and representative drugs that target this system. 
Recently, the efforts to design and synthesize renin inhibitors were met with success with the discovery of the drug aliskiren [3]. Today, we have gained more knowledge on RAS: First, we know that more biochemical pathways are affecting the conversion of angiotensinogen to Ang II; second, although Ang II affects mainly two GPCR receptor subtypes, namely $\mathrm{AT}_{1} \mathrm{R}$ and $\mathrm{AT}_{2} \mathrm{R}$, at least four different subtypes have been identified (designated as $\mathrm{AT}_{1} \mathrm{R}, \mathrm{AT}_{2} \mathrm{R}, \mathrm{AT}_{3} \mathrm{R}$ and $\mathrm{AT}_{4} \mathrm{R}$ [4]). Also, the different metabolites of Ang II, which form after proteolytic degradation of the parent molecule, present biological activity. In addition, Ang II has high binding affinity to neurolysin which in turn may affect significantly the activity on RAS [5-7]. The action of Ang II on AT 1 R was the first to be studied in detail, while the mode of action of $\mathrm{AT}_{2} \mathrm{R}$ remained elusive for a long time owing to the lack of ligands that selectively target this receptor as also due to its low expression [8-11]. The recent discovery of novel ligands that selectively target these receptor subtypes has paved the way to deconvolute the functions of $\mathrm{AT}_{1} \mathrm{R}$ and $\mathrm{AT}_{2} \mathrm{R}$. Furthermore, new functions of the two receptors have been revealed. It is now shown that $\mathrm{AT}_{1} \mathrm{R}$ and $\mathrm{AT}_{2} \mathrm{R}$ present opposing biological functions, e.g., $\mathrm{AT}_{2} \mathrm{R}$ has anti-proliferative properties [12,13], while $\mathrm{AT}_{1} \mathrm{R}$ facilitates angiogenesis and cellular proliferation [12,14]. Furthermore, besides the classical functions mediated by the $\mathrm{AT}_{1} \mathrm{R}$ like vasoconstriction, proliferation of vascular smooth muscle and cardiac cellular growth, a direct correlation has been identified between the up-regulation of $\mathrm{AT}_{1} \mathrm{R}$ and the immunosuppression and invasiveness state in many cancer types, establishing $\mathrm{AT}_{1} \mathrm{R}$ as a potential cancer drug target [15-19]. Respectively, the discovery of new ligands that selectively target $\mathrm{AT}_{2} \mathrm{R}$ has encouraged the scientific community to explore in detail functions orchestrated and associated by $\mathrm{AT}_{2} \mathrm{R}$. For instance, $\mathrm{AT}_{2} \mathrm{R}$ adopts a protective role in pathological conditions such as tissue injury and inflammation [20], diabetic neuropathy [21], stroke damage [22], diabetes type 2 [23], spinal cord injury [24] and cancer [25,26]. The accumulating body of evidence highlights the enhanced potential of both $\mathrm{AT}_{1} \mathrm{R}$ and $\mathrm{AT}_{2} \mathrm{R}$ to act as important pharmaceutical targets for a diverse array of pathologies. In light of this, it is worth collating the principles that govern selectivity on these two subtype receptors and utilize these to design and develop the new generation of more selective compounds.

As with renin and ACE inhibitors, extensive rational design plans had to be implemented by researchers working both in industry and academia to discover $\mathrm{AT}_{1} \mathrm{R}$ antagonists. Initially, efforts were mainly focused on peptides, but owing to the known disadvantages that peptides encounter they could not enter clinical trials or the market as drugs. However, these studies provided valuable SAR knowledge. From peptides, the scientists have been led to small organic molecules that mimicked the C-terminal segment of Ang II (Figure 2).

The first $\mathrm{AT}_{1} \mathrm{R}$ antagonist that entered the market was losartan [ $\mathrm{IC}_{50}=5.5 \mathrm{nM}$ [27] (binding to human $\mathrm{AT}_{1} \mathrm{R}$ using as radioligand ${ }^{125} \mathrm{I}\left[\mathrm{Sar}^{1}-\mathrm{Ile}^{8}\right] \mathrm{Ang}$ II), $150 \mathrm{nM}$ [28] (inhibition of [ $\left.{ }^{125} \mathrm{I}\right] \mathrm{Ang}$ II $(0.2 \mathrm{nM})$ binding to bovine adrenal cortical membranes), $6.7 \mathrm{nM}$ [29] (displacement of [ $\left.{ }^{125} \mathrm{I}\right] \mathrm{Sar}^{1}, \mathrm{Ile}^{8}-\mathrm{Ang}$ II specifically bound to $\mathrm{AT}_{1} \mathrm{R}$ in rat hepatic membranes)]. The success of losartan followed eight more derivatives constituting the class of SARTANs or angiotensin receptor blockers (ARBs) (Figures 2 and 3). 


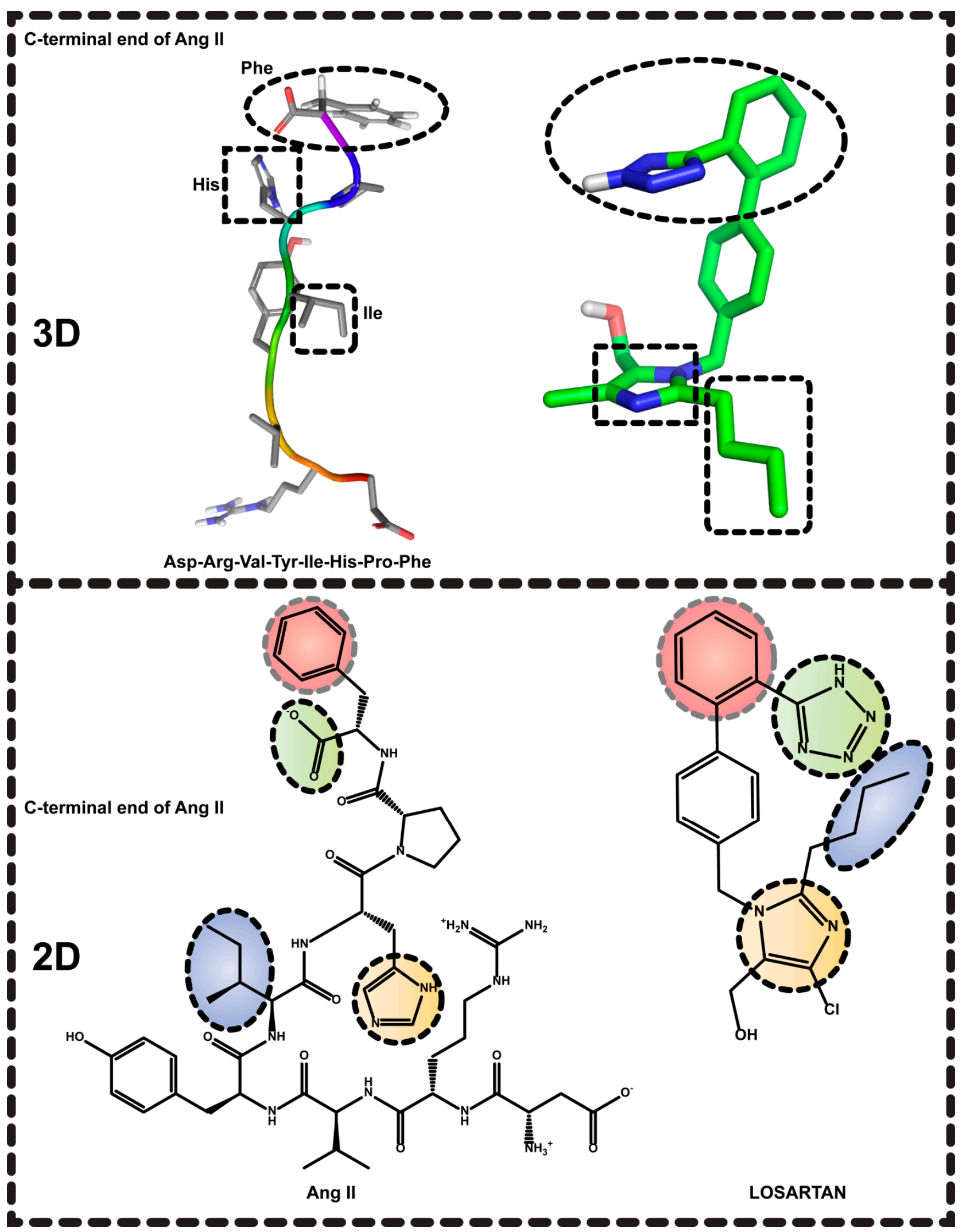

Figure 2. (top, left) A 3D proposed model of Ang II. (top, right) A 3D structure of losartan. Circled or squared segments of the two molecules illustrate common pharmacophores. Circled common pharmacophores are shown for the 2D structures of Ang II (top, left) and losartan (bottom, right). 


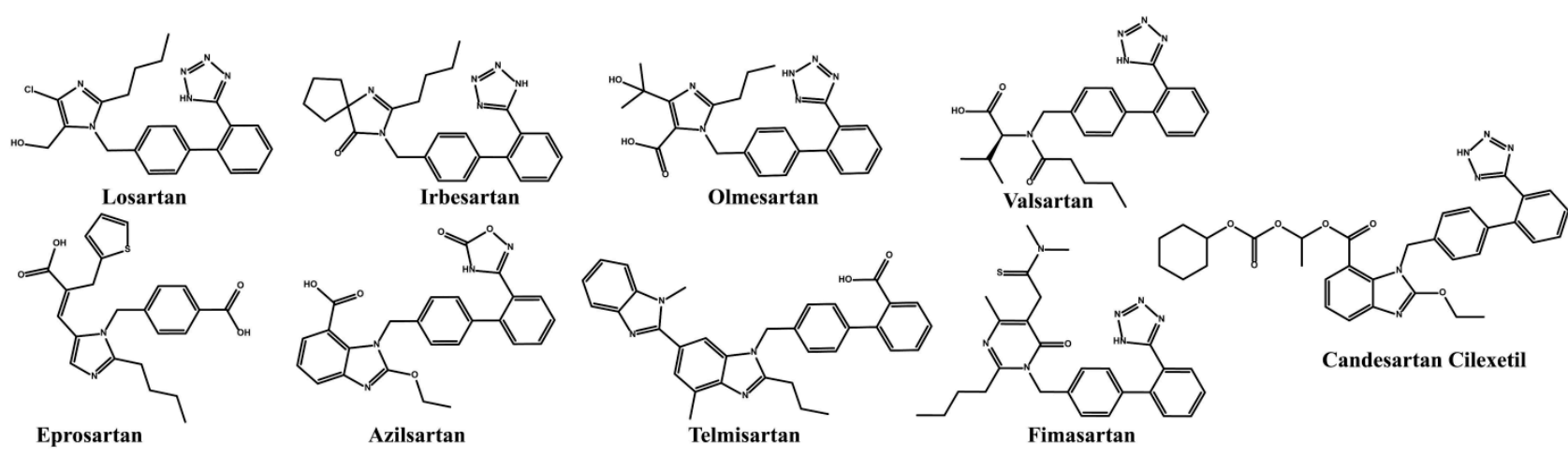

$\mathrm{AT}_{1} \mathrm{R}$ antagonists

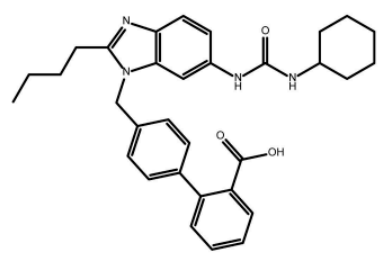

BIBS-39

$\mathrm{IC}_{50} \mathrm{AT}, \mathrm{R}=29 \mathrm{nM}$

$\mathrm{IC}_{50} \mathrm{AT}_{2} \mathrm{R}=480 \mathrm{nM}$
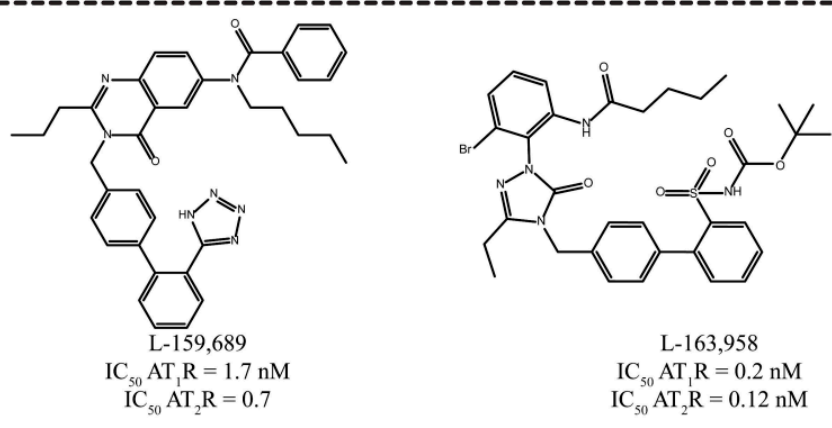

L-163,958

$\mathrm{IC}_{50} \mathrm{AT}_{1} \mathrm{R}=0.2 \mathrm{nM}$

$\mathrm{IC}_{50} \mathrm{AT}_{2} \mathrm{R}=0.12 \mathrm{nM}$

Balanced AT $R / A T$ T $R$ antagonists

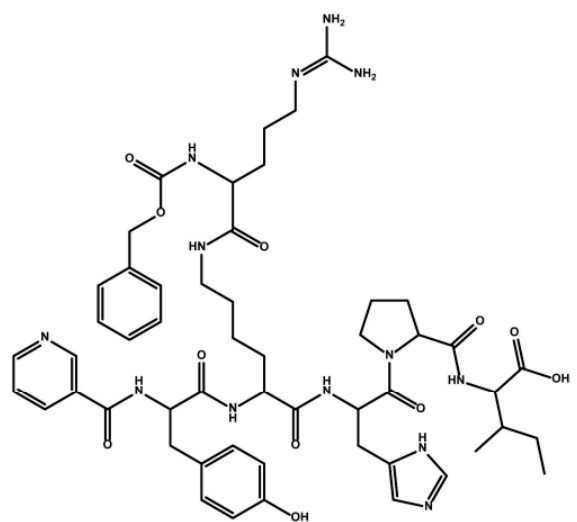

CGP-42112

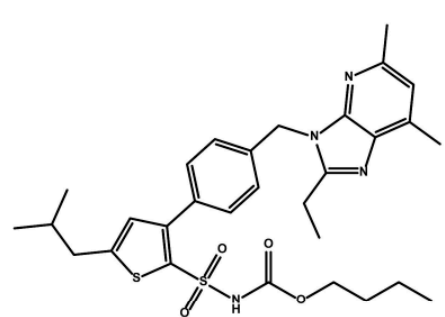

L-162,313

AT $R$ agonists

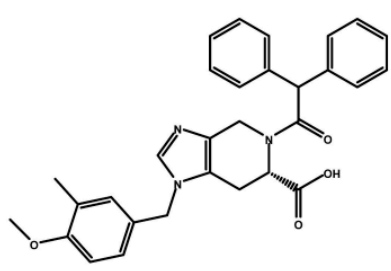

EMA300

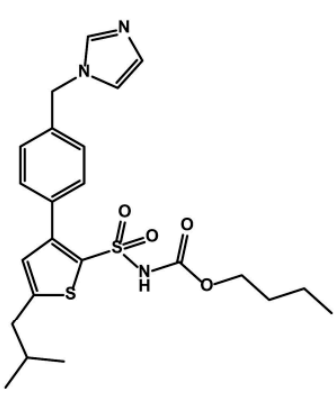

M024/C21
EMA401

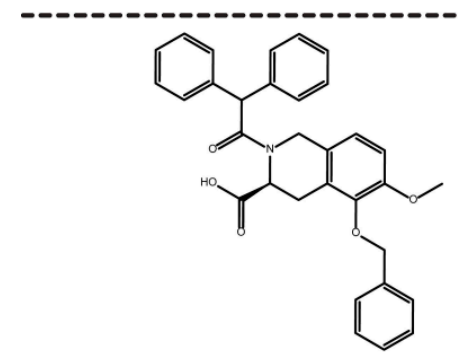

\section{$\mathrm{AT}_{2} \mathrm{R}$ antagonists}

Figure 3. $\mathrm{AT}_{1} \mathrm{R}$ antagonists, $\mathrm{AT}_{1} \mathrm{R} / \mathrm{AT}_{2} \mathrm{R}$ hybrids, $\mathrm{AT}_{2} \mathrm{R}$ antagonists and agonists.

As mentioned above, for a long time the scientific community neglected $\mathrm{AT}_{2} \mathrm{R}$ and its major physiological role remained elusive [9,30-32]. However, the design and synthesis of the selective $\mathrm{AT}_{2} \mathrm{R}$ antagonist PD 123,319 [33] and the selective $\mathrm{AT}_{2} \mathrm{R}$ agonist CGP-42112A [34], the selective 
agonist M024/C21 [35] and the selective $\mathrm{AT}_{2} \mathrm{R}$ antagonist EMA401 that entered clinical trials for the treatment of neurophathic pain [36] led to an understanding of the physiological role of this receptor and the design and synthesis of molecules possessing beneficial effects [36,37]. Ichiki et al. and Rein et al. $[38,39]$ reported that mice lacking $\mathrm{AT}_{2} \mathrm{R}$ exhibited a higher $\mathrm{BP}$ and higher sensitivity to an angiotensin II-induced hypertensive effect than normal mice. This information triggered the effort towards the discovery of $\mathrm{AT}_{2} \mathrm{R}$ agonists as antihypertensive targets. Speth et al. [40] synthesized [ $p$-amino-Phe6] Ang II and more recently Yamada et al. [41], discovered the peptide novokinin as an $\mathrm{AT}_{2} \mathrm{R}$ agonist possessing antiopioid and anorexigenic activity only on $\mathrm{AT}_{2} \mathrm{R}$.

Novokinin (RPLKPW) was designed based on ovokinin (FRADHPFL), a vasorelaxing peptide derived from ovalbumin. Its vasorelaxing activities were blocked by PD123,319, an $\mathrm{AT}_{2} \mathrm{R}$ antagonist. Guimond et al. [42], recently proved that the octapeptides saralasin and sarile act as $\mathrm{AT}_{2} \mathrm{R}$ agonists. A method to regulate ligand selectivity for $\mathrm{AT}_{1} \mathrm{R}$ and $\mathrm{AT}_{2} \mathrm{R}$ through controlling aromatic-prolyl interactions in Ang II, by tuning aromatic electronics has recently been presented [26]. This method was used to investigate substituent effects on the para-position of phenylalanine installed at position 6 of Ang II (4-x-Phe ${ }^{6}$. The analogue bearing an electron donor $(-\mathrm{OH})$ group was a highly selective $\mathrm{AT}_{2} \mathrm{R}$ agonist with a $K_{\mathrm{i}}$ of $3 \mathrm{nM}$ that also pinpointed inhibitory activity against breast carcinoma cell proliferation at $\mathrm{nM}$ concentration.

Overproduction of Ang II in pathological states has harmful effects on many systems, and the design and synthesis of more selective $\mathrm{AT}_{1} \mathrm{R}$ antagonists and $\mathrm{AT}_{2} \mathrm{R}$ agonists and antagonists is expected to lead to drugs with multiple benefits. Already, $\mathrm{AT}_{1} \mathrm{R}$ antagonists in the market are clearly characterized by their antihypertensive effects [43].

This review article focuses on recent efforts on the design and synthesis of small bioactive molecules that can act on $\mathrm{AT}_{1} \mathrm{R}$ and $\mathrm{AT}_{2} \mathrm{R}$. For molecules synthesized before 2010, which act on $\mathrm{AT}_{1} \mathrm{R}$, the reader can get detailed information from the cited review [44]. Emphasis will be also given to recent synthetic efforts to develop multitarget drugs that have structural components recognized by $\mathrm{AT}_{1} \mathrm{R}$ and $\mathrm{AT}_{2} \mathrm{R}[45]$.

In addition to the synthetic efforts in the recent years, parallel attempts have been made to model the two receptors using new approaches. Without doubt, these approaches can aid the design and synthesis of new molecules acting on the two receptors. Review articles covering these efforts until 2011 can be found in the literature [44,46], and thus this review will focus on the efforts after 2011.

Finally, general conclusions on the future prospects of the recent discoveries will be presented. Our hope is that this article will assist medicinal chemists to design, synthesize and discover new drugs possessing beneficial effects for major diseases such as cardiovascular and cancer.

\section{Results and Discussion}

\subsection{Novel Synthetic Molecules Acting on the $A T_{1} R$}

Agelis et al. [47,48] synthesized a series of symmetrically bis-substituted imidazole analogues bearing at N-1 and N-3 two biphenyl moieties ortho-substituted either with tetrazole or carboxylate groups. Among them, the imidazolium 1 (BV6, Scheme 1) showed superior antagonistic activity and receptor affinity to that of losartan $[47,49]$. The same team studied the interactions of the imidazolium 
1 with lipid bilayers and its delivery into a mesoporous silicate drug delivery matrix SBA-15 [49]. Both its interactions with membranes and delivery properties point out that its structural modifications may lead to a drug molecule. The imidazolium 1 was accommodated in $\mathrm{AT}_{1} \mathrm{R}$ with more favored lipophilic interactions with respect to the prototype losartan which may account for its high activity (Figure 4).

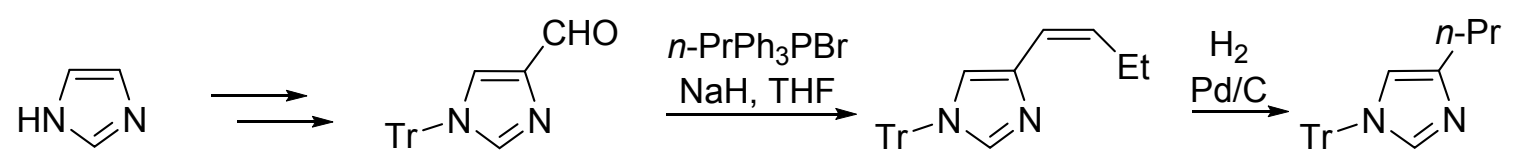

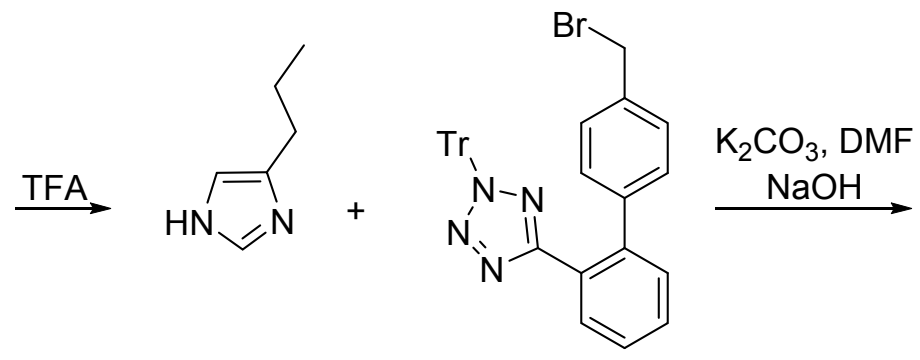

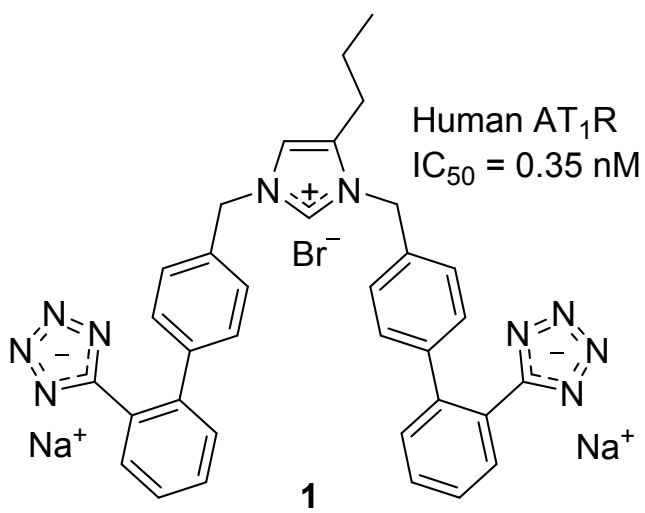

Scheme 1. Outline of the synthesis of the imidazolium 1 (named BV6 in the published article [47]). Experiments were performed with the human $\mathrm{AT}_{1} \mathrm{R}$ and the radioligand ${ }^{125} \mathrm{I}\left[\mathrm{Sar}^{1}-\mathrm{Ile}^{8}\right]$ Ang II (1000 nM).
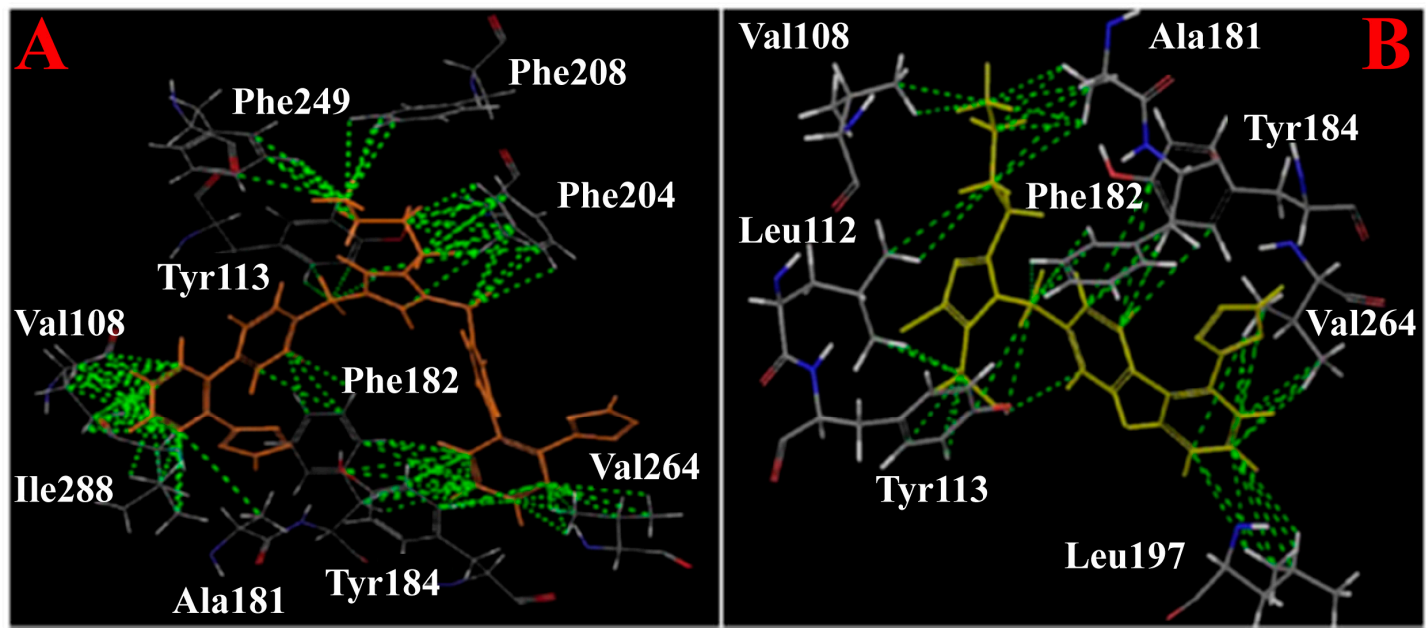

Figure 4. The hydrophobic interactions of the imidazolium $\mathbf{1}$ in $\mathbf{A}$ and of losartan in $\mathbf{B}$ with $\mathrm{AT}_{1} \mathrm{R}$. Imidazolium $\mathbf{1}$ exerts more hydrophobic interactions owing to its additional biphenyl tetrazole segment.

The synthetic molecule 2 (Scheme 2) bears a bioisosteric replacement of the $\mathrm{CH}_{2}$ bridge between the biphenyl system and the nitrogen heterocyle by an NH moiety [50]. 


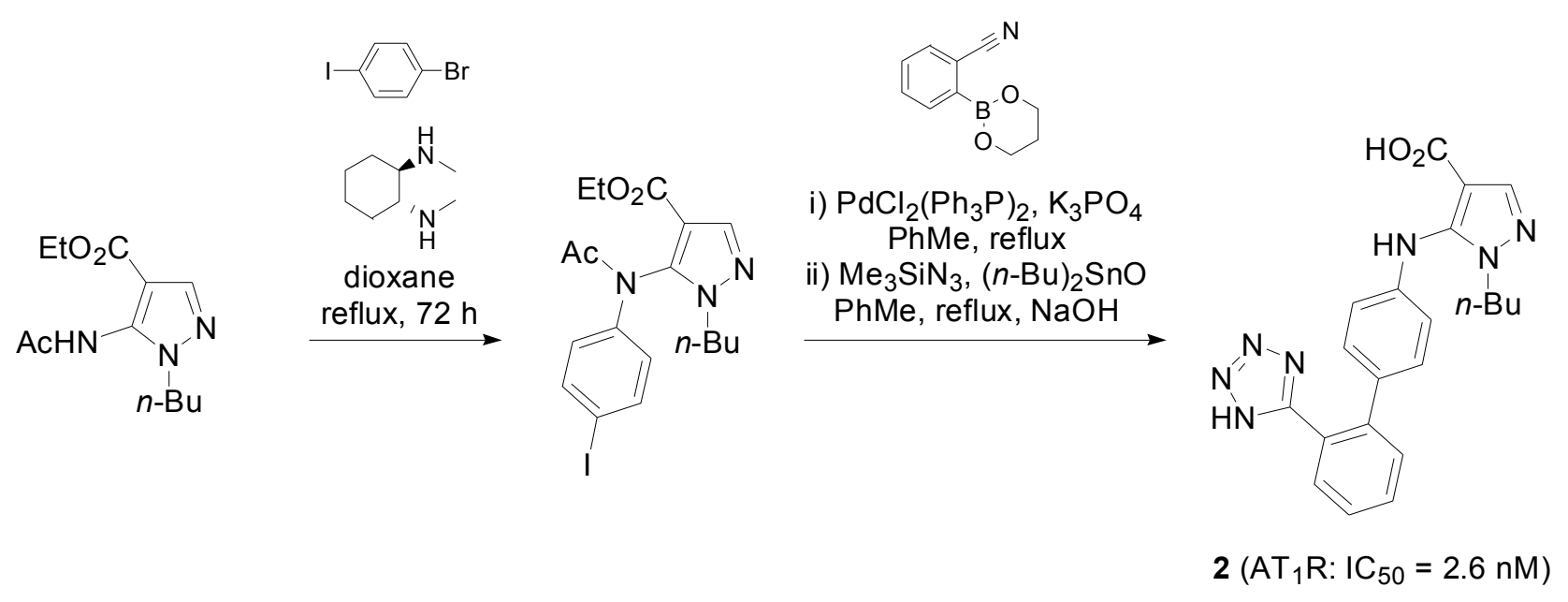

Scheme 2. Outline of the synthesis of $\mathbf{2}$. The binding activity of the compound was determined in human recombinant $\mathrm{AT}_{1} \mathrm{R}$ using as radioligand ${ }^{125} \mathrm{I}\left[\mathrm{Sar}^{1}, \mathrm{Ile}^{8}\right]$ Ang II $(0.05 \mathrm{nM})$.<smiles>Cc1cc(C(=O)O)cc2[nH]c(CC(=O)NCCc3ccccc3)nc12</smiles><smiles>CC(=O)c1ccccc1-c1ccc(CBr)cc1</smiles>

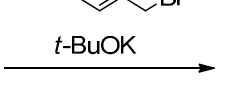<smiles>CCCc1nc2c(C)cc(C(=O)NCCc3ccccc3)cc2n1Cc1ccc(-c2ccccc2C(C)C)cc1</smiles>

$\mathrm{NaOH}, \mathrm{MeOH}$

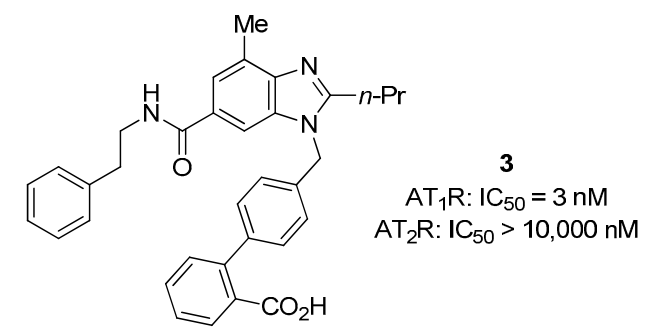

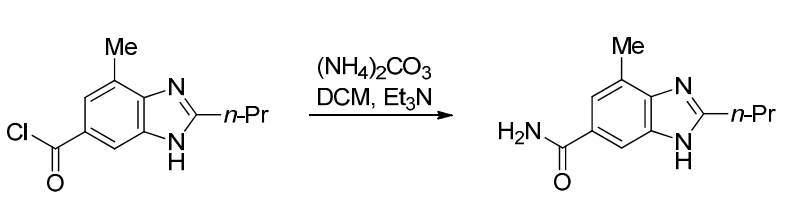<smiles>COC(=O)c1ccccc1-c1ccc(Br)cc1</smiles><smiles>CCCc1nc2c(C)cc(C(N)=O)cc2n1Cc1ccc(-c2ccccc2C(C)(C)C)cc1</smiles>
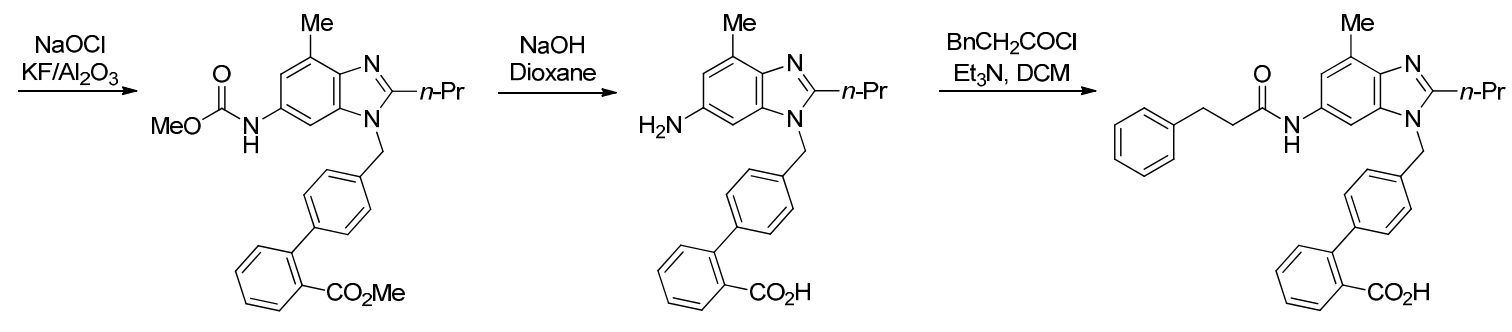

$A T_{1} R: I_{50}=0.1 \mathrm{nM}$ $A T_{2} R: I C_{50}=149 \mathrm{nM}$

Scheme 3. Outline of the synthesis of of 3 and 4. The binding activities of the compounds were determined in $\mathrm{AT}_{1} \mathrm{R}$ and $\mathrm{AT}_{2} \mathrm{R}$ using as radioligand ${ }^{125} \mathrm{I}\left[\mathrm{Sar}^{1}, \mathrm{Ile}^{8}\right]$ Ang II (25 pM). 
Compounds 3 and 4 (Scheme 3) were synthesized by Zhang et al. [51], and are promising selective $\mathrm{AT}_{1} \mathrm{R}$ antagonists. Da et al. [52], synthesized fluorine substituted derivatives of losartan, valsartan and irbesartan with carboxylic acid group as replacement to the known potent tetrazole moiety at the 2'-biphenyl position.

The biphenyl 5 (Scheme 4) showed an efficient and long lasting effect in reducing blood pressure which lasted more than $24 \mathrm{~h}$ at a dose of $10 \mathrm{mg} / \mathrm{kg}$ in spontaneous hypertensive rats (SHR), which was much better than controls losartan and valsartan. In addition to antihypertensive property, the biphenyl 5 also inhibited prostate cancer in vitro and in vivo.

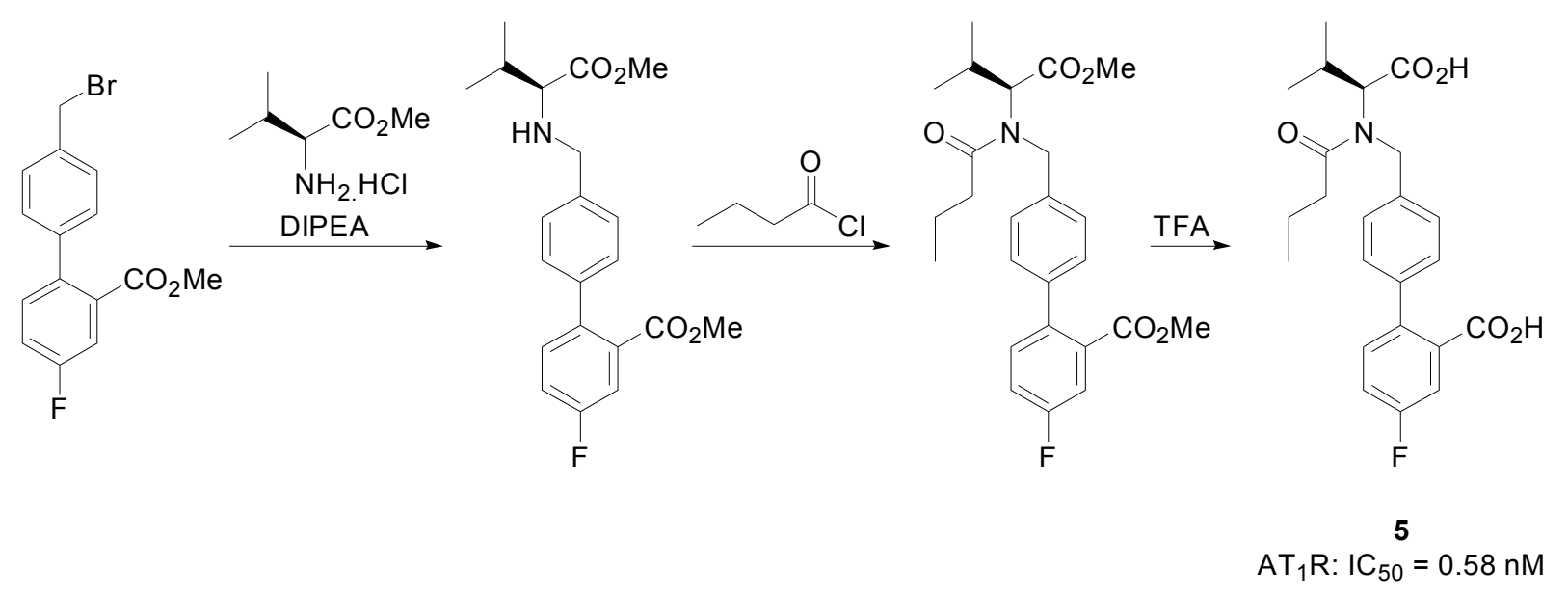

Scheme 4. Outline of the synthesis of the biphenyl 5. Binding assays were performed using vascular smooth muscle cells obtained from thoracic aorta of rats, using ${ }^{125} \mathrm{I}\left[\mathrm{Sar}^{1}, \mathrm{Ile}^{8}\right]$ Ang II as radioligand at a concentration of $0.1 \mathrm{nM}$.

The 5-nitrobenzimidazole 6 (Scheme 5) exerts high nanomolar and durable activity $\left(\mathrm{IC}_{50}=1.03 \pm\right.$ $0.26 \mathrm{nM}$ ) in vascular smooth muscle cells [53]. This compound bears an indole benzoic ring instead of the biphenyl scaffold with an acidic segment attached at the ortho position, (a common feature to commercial drugs except eprosartan that contains only one phenyl ring) [53].
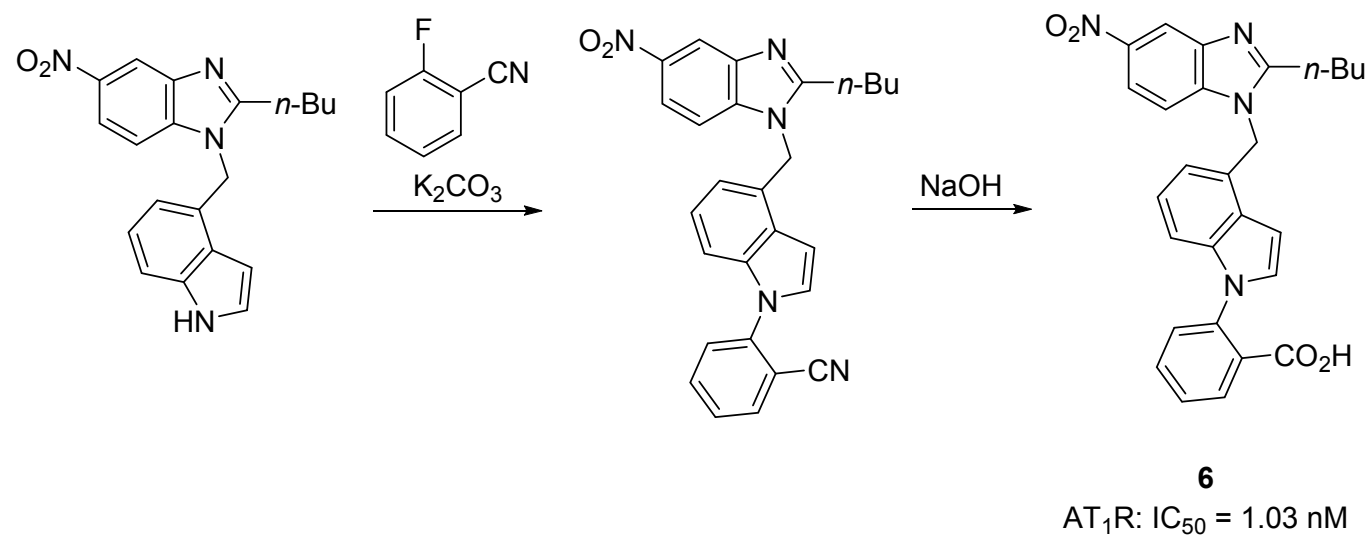

Scheme 5. Outline of the synthesis of the benzimidazole 6. The radioligand binding assay were performed using vascular smooth muscle cells obtained from thoracic aorta of rats, using ${ }^{125} \mathrm{I}\left[\mathrm{Sar}^{1}, \mathrm{Ile}^{8}\right]$ Ang II $(0.1 \mathrm{nM})$ as radioligand. 
New $\mathrm{AT}_{1} \mathrm{R}$ antagonists were designed and evaluated based on a central pyrrolidine system bearing biphenyl-tetrazoles or biphenylcarboxylic acids at the N12, C-3 and C-4 positions [54]. Among them compound 7 (Scheme 6) was the most promising and had 2-fold higher hypotensive activity than losartan and similar level of antihypertensive activity to losartan with LD50 value of $117 \mu \mathrm{g} / \mathrm{Kg}$ demonstrating in this way the high safety margin of the compound. The compound was evaluated in vivo for hypotensive activity on normotensive rats.

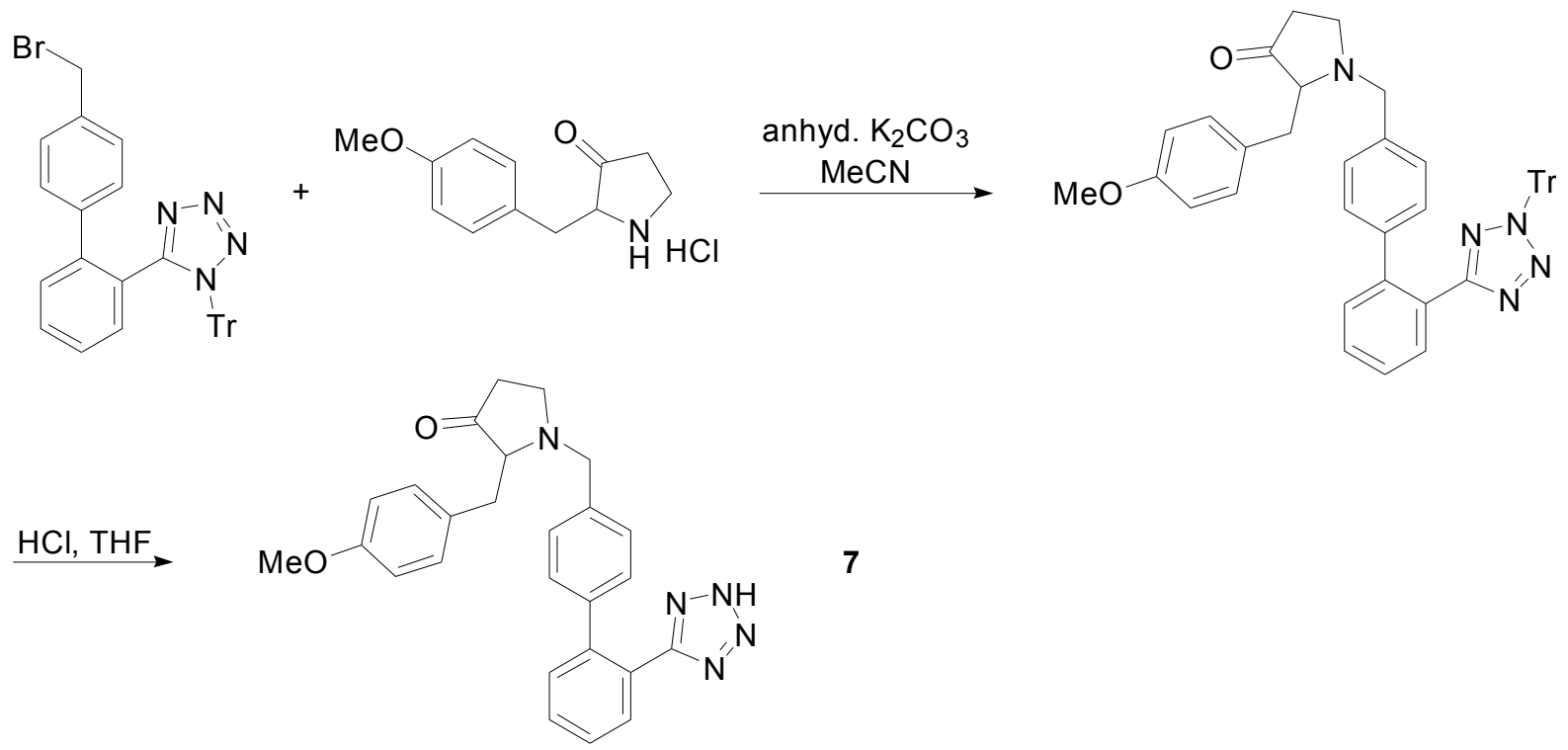

Scheme 6. Outline of the synthesis of the pyrrolidone 7.

A series of compounds based on the $\alpha 1$-adrenoreceptor antagonist drug urapidil and molecular modeling were synthesized. Compound 8 (Scheme 7) exhibited hypotensive activity more or less similar to losartan [55]. The in vivo biological evaluation was carried out on normotensive adult rats.

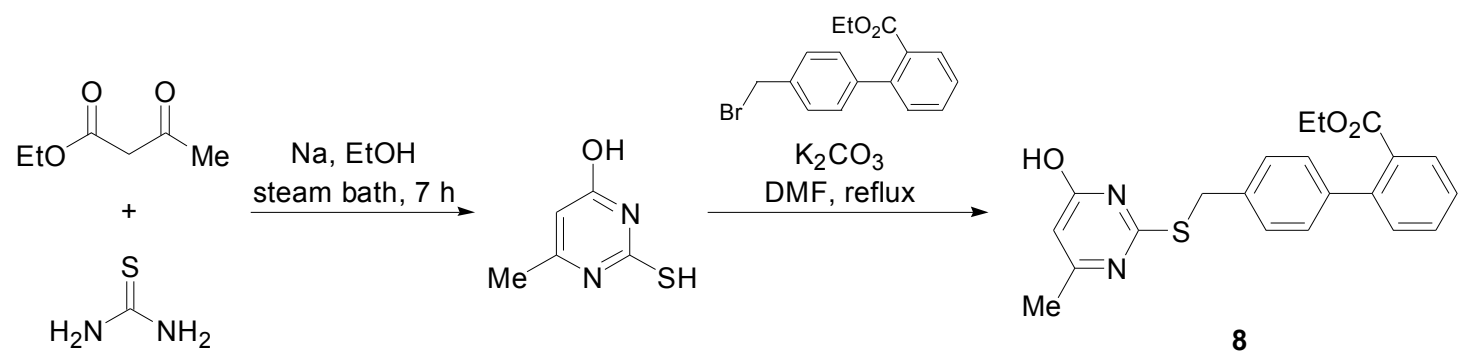

Scheme 7. Outline of the synthesis of compound $\mathbf{8}$.

The presented examples illustrate that there is still space for developing novel bioactive $\mathrm{AT}_{1} \mathrm{R}$ antagonists. Novel ideas such as the design and synthesis of molecules bearing more lipophilic segments that fit in the AT 1 R certainly will provide impetus in the field.

\section{2. $A_{2} R$ Agonists and Antagonists}

Establishing ligands that will present enhanced selectivity for $\mathrm{AT}_{2} \mathrm{R} v s$. $\mathrm{AT}_{1} \mathrm{R}$ is based on the fact that $\mathrm{AT}_{2} \mathrm{R}$ antagonizes the functions of $\mathrm{AT}_{1} \mathrm{R}$. Activation of $\mathrm{AT}_{2} \mathrm{R}$ leads to apoptosis, antiproliferation 
and vasodilation, whereas activation of $\mathrm{AT}_{1} \mathrm{R}$ leads to cellular growth, proliferation and vasoconstriction [26].

These results have highlighted the potential of $\mathrm{AT}_{2} \mathrm{R}$ to act as a novel drug target in tissue regeneration and protection through controlling apoptosis, fibrosis and inflammation [56], heart failure [57], and cancer [25,26].

Wan et al. synthesized the first selective nonpeptide $\mathrm{AT}_{2} \mathrm{R}$ agonist M024/C21 by stepwise simplification of the nitrogen containing heterocyclic ring system [11,35,58,59]. The substitution of the thienyl-phenyl to the biphenyl scaffold (resembling L-162,782, Figure 5) produced the equipotent compound $9\left[K_{\mathrm{i}}\left(\mathrm{AT}_{1} \mathrm{R}\right)>10,000 \mathrm{nM}, K_{\mathrm{i}}\left(\mathrm{AT}_{2} \mathrm{R}\right)=0.7 \mathrm{nM}\right][58,60]$ showing that the two scaffolds are bioisosteric in these compounds. Compound 10, a derivative of L-162,782, was synthesized by Liu et al. [61], in an attempt to develop new $\mathrm{AT}_{2} \mathrm{R}$ agonists as novel antihypertensive candidates (Scheme 8). The compound was superior to the reference drug losartan in SHRs and it had no significant impact in heart rate.

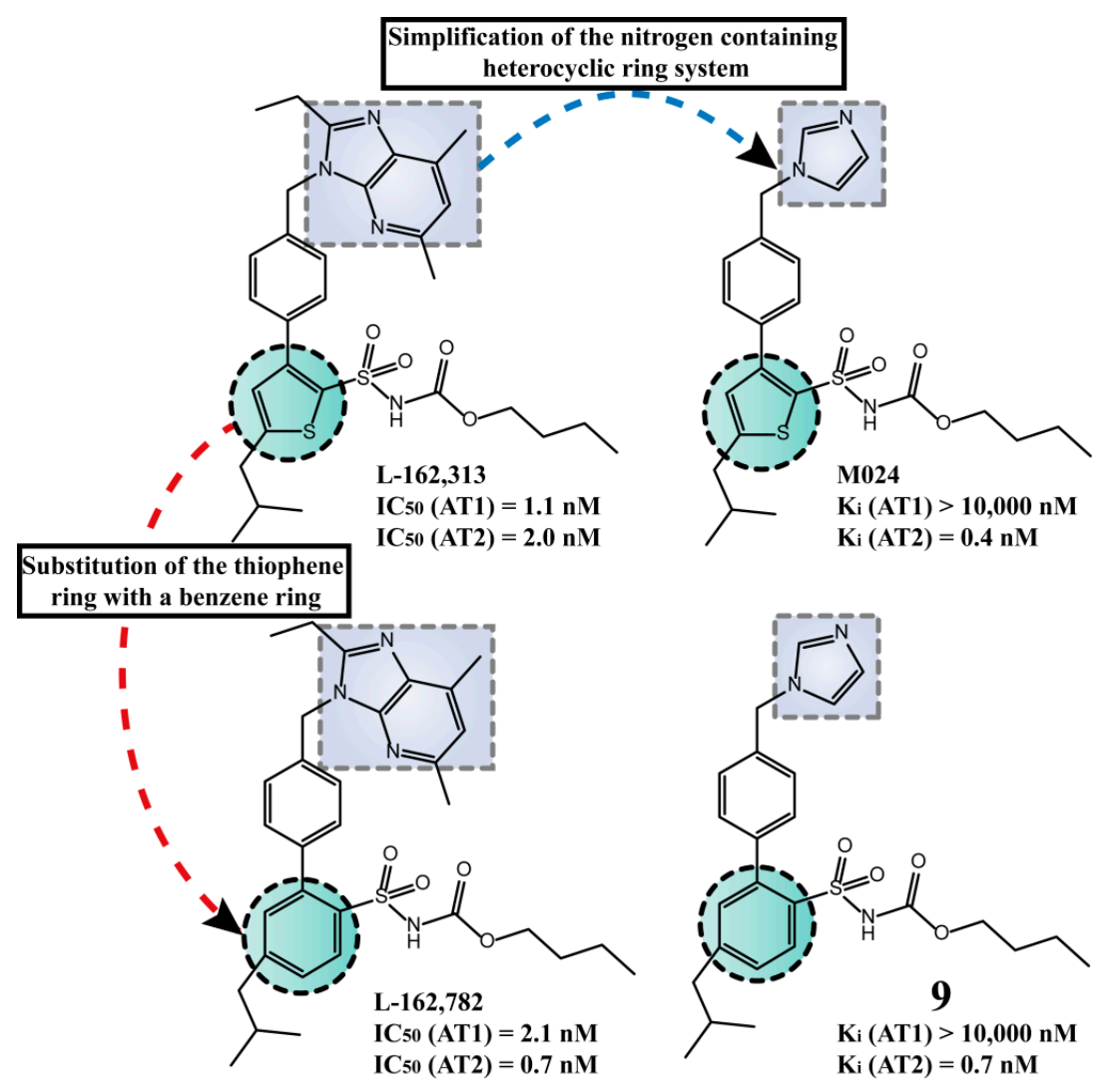

Figure 5. Structural modifications performed on the original scaffold to lead to the highly selective $\mathrm{AT}_{2} \mathrm{R}$ agonist $\mathbf{9}$. The activity of compound $\mathbf{9}$ was evaluated in binding assay using $\mathrm{AT}_{1} \mathrm{R}$ from rat liver membranes and $\mathrm{AT}_{2} \mathrm{R}$ from pig uterus membranes, while $\left[{ }^{125} \mathrm{I}\right] \mathrm{Ang} \mathrm{II}$ $(0.03 \mathrm{nM})$ was used as radioligand.

Mahalingam et al. [62], synthesized derivatives of $\mathrm{AT}_{2} \mathrm{R}$ agonist M024/C21 (Figure 3) in an attempt to reduce the CYP450 inhibitory property. The best analogue prepared was compound $\mathbf{1 1}$ (Scheme 9) which induced neurite elongation in NG 108-15 cells and served as a potent and selective $\mathrm{AT}_{2} \mathrm{R}$ agonist. 


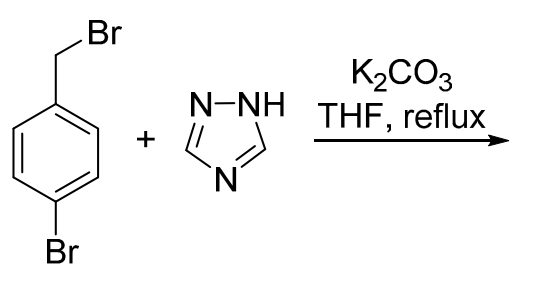<smiles>CC(C)Cc1ccc(S(=O)(=O)NC(C)(C)C)c([B]O)c1COc1ccccc1</smiles><smiles>CC(C)Cc1ccc(S(N)(=O)=O)c(-c2ccc(Cn3cncn3)cc2)c1</smiles><smiles>CCCCOC(=O)Cl</smiles><smiles>CCCCOC(=O)NS(=O)(=O)c1ccc(CC(C)C)cc1-c1ccc(Cn2cncn2)cc1</smiles>

10

$A T_{2} R: I C_{50}=0.4 \mathrm{nM}$ $A T_{1} R: I_{50}>10,000 \mathrm{nM}$

Scheme 8. Outline of the synthesis of $\mathbf{1 0}$. AT $\mathrm{T}_{1} \mathrm{R}$ affinity assay was determined using rat liver membrane, while porcine myometrial membrane was used for $\mathrm{AT}_{2} \mathrm{R}$. [ $\left.{ }^{125} \mathrm{I}\right]$ Ang II was used as radioligand $(0.03 \mathrm{nM})$.<smiles>CC(C)Cc1cc(Br)c(S(=O)(=O)NC(C)(C)C)s1</smiles><smiles>CC(C)Cc1cc(-c2ccc(N3CCCC3=O)cc2)c(S(=O)(=O)NC(C)(C)C)s1</smiles><smiles>CC(C)Cc1cc(-c2ccc(N3CCCC3=O)cc2)c(S(N)(=O)=O)s1</smiles><smiles>CCCCOC(=O)Cl</smiles>

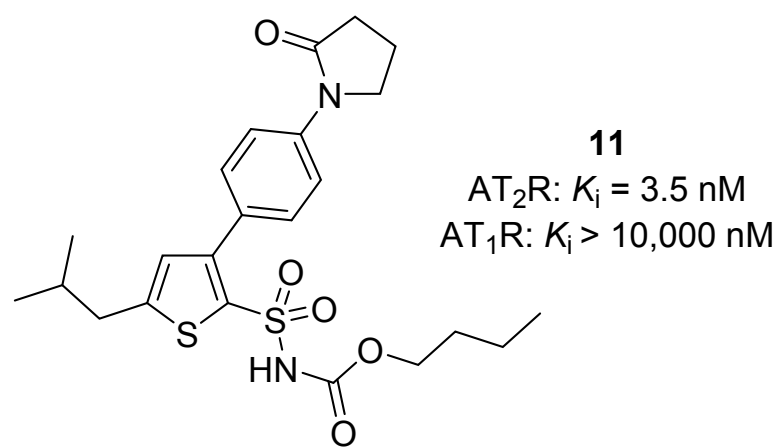

Scheme 9. Outline of the synthesis of compound 11. Affinity assay was conducted as descripted in the previous example. 
Murugaiah et al. synthesized novel compounds derivatives of M024/C21 which are meta- rather than para-substituted on the phenyl $[35,63,64]$. Interestingly, they generated $\mathrm{AT}_{2} \mathrm{R}$ antagonists in comparison to $\mathrm{M} 024 / \mathrm{C} 21$, which is a selective $\mathrm{AT}_{2} \mathrm{R}$ agonist. Compound $\mathbf{1 2}$ is a selective $\mathrm{AT}_{2} \mathrm{R}$ antagonist (Figure 6).
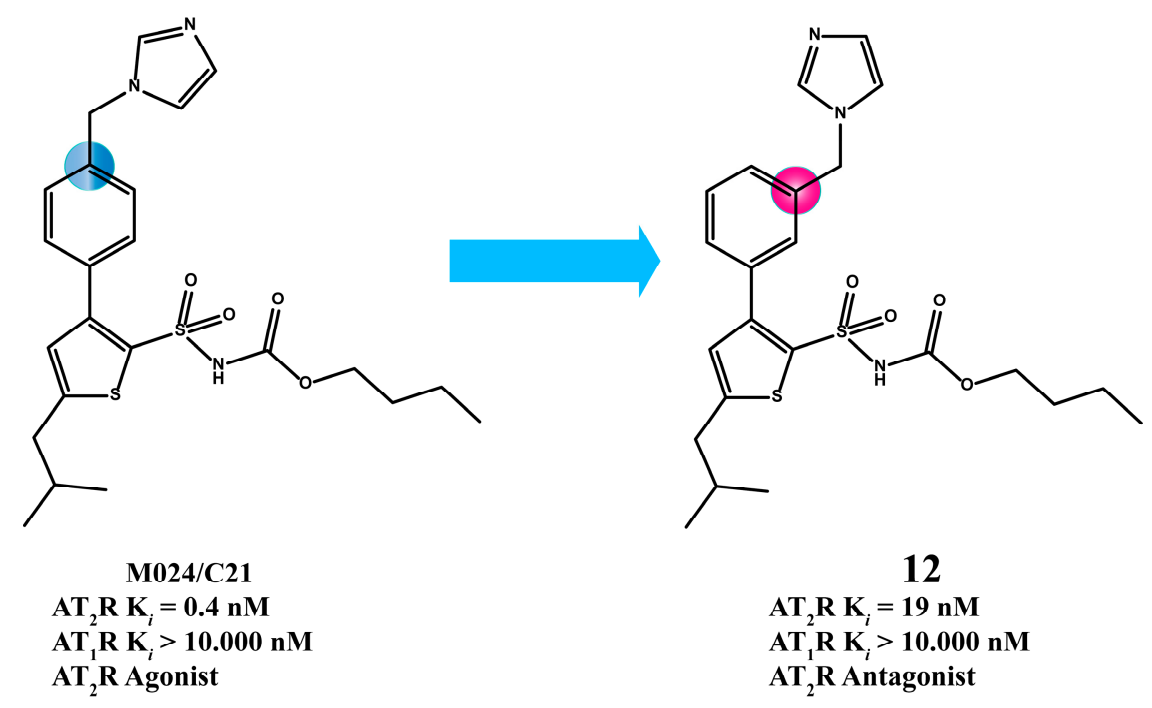

Figure 6. The analogue 12 that bears a meta-substituted phenyl is an $\mathrm{AT}_{2} \mathrm{R}$ antagonist, in contrast to M024/C21 which bears para-substituted phenyl and is an $\mathrm{AT}_{2} \mathrm{R}$ selective agonist. The dissociation constant $K_{\mathrm{i}}$ values were determined as described in the previous example.

Veron et al. [65], used compound $\mathbf{1 3}$ as a lead to synthesize sixteen new C-terminally modified analogues. Compound $\mathbf{1 3}$ bears structural similarities with the C-terminal segment of Ang II. Specifically, it contains a carboxylate group as $\mathrm{Phe}^{8}$, isoleucine side chain instead of benzene of $\mathrm{Phe}^{8}$ and imidazole ring as $\mathrm{His}^{6}$ [66]. Compound 14 proved the most active and was over 12-fold more potent than the lead compound 13 (Figure 7). All the synthesized compounds were evaluated for their human $\mathrm{AT}_{2} \mathrm{R}$ affinity in a radioligand binding assay measuring the displacement of $\left[{ }^{125} \mathrm{I}\right] \mathrm{CGP}-42112 \mathrm{~A}$, a selective $\mathrm{AT}_{2} \mathrm{R}$ agonist.

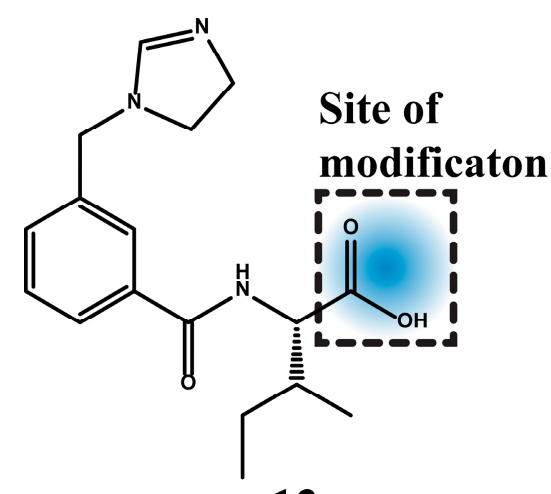

13

Human $\mathrm{AT}_{2} \mathrm{R}_{i}=110 \mu \mathrm{M}$

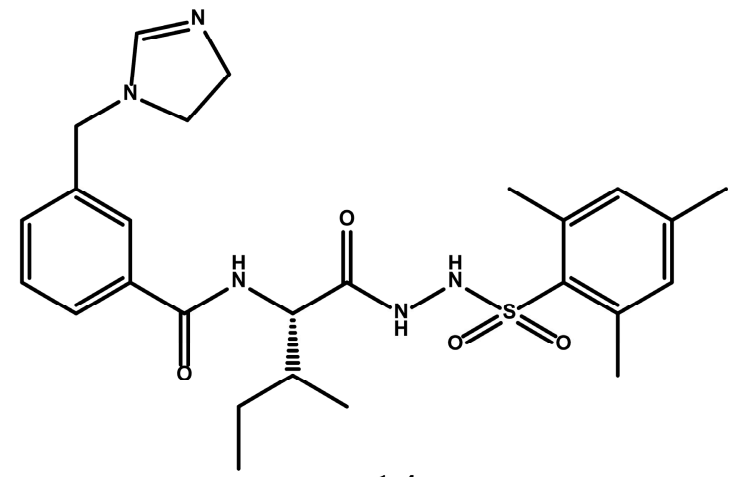

14

Human $\mathrm{AT}_{2} \mathbf{R ~ K}_{i}=8.5 \mu \mathrm{M}$

Figure 7. The synthetic compound $\mathbf{1 4}$ possesses improved $\mathrm{AT}_{2} \mathrm{R}$ activity compared to the lead compound 13. 
Behrends et al. [67], also used compound $\mathbf{1 3}$ as a lead to evaluate fifteen new synthetic compounds. Thirteen of them showed higher activity than the lead compound 13. An example of the synthesis of analogue $\mathbf{1 5}$ is given below (Scheme 10). Binding assays were performed with recombinant human $\mathrm{AT}_{2} \mathrm{R}$ or $\mathrm{AT}_{1} \mathrm{R}$ and relying on the displacement of $\left[{ }^{125} \mathrm{I}\right] \mathrm{CGP}-42112\left(\mathrm{AT}_{2} \mathrm{R}\right)$ and $\left[{ }^{125} \mathrm{I}\right]\left[\mathrm{Sar}^{1}, \mathrm{Ile}^{8}\right]$ Ang II.

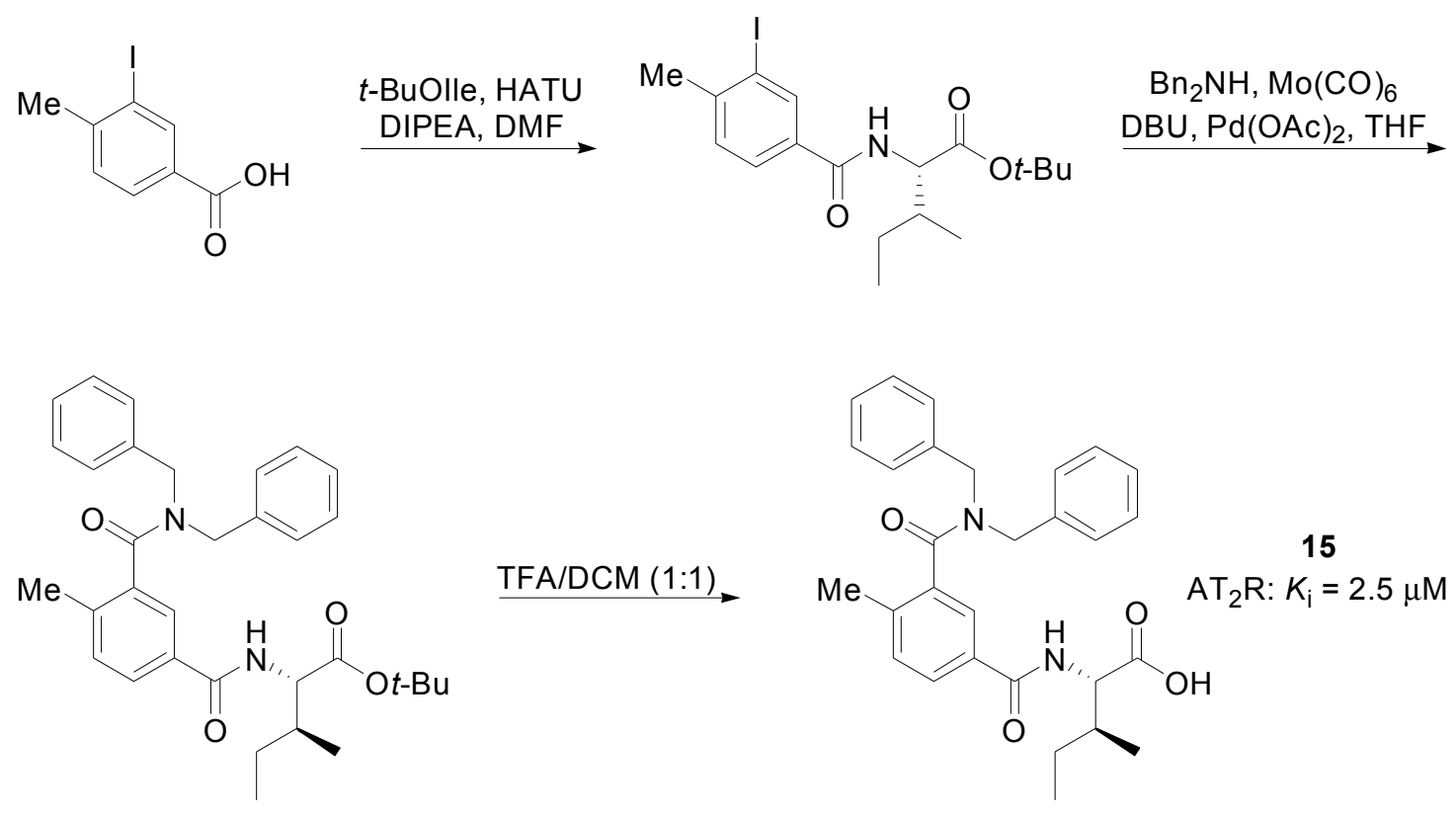

Scheme 10. Outline of the synthesis of compound $\mathbf{1 5 .}$

From the above examples, it is clear that the discovery of new $\mathrm{AT}_{2} \mathrm{R}$ agonists and antagonists is still in its infancy. Only recently the interest was increased on $\mathrm{AT}_{2} \mathrm{R}$ and of course more time is needed to tune the requirements for selectivity of $\mathrm{AT}_{2} \mathrm{R}$ agonism/antagonism $v s$. AT $1 \mathrm{R}$ agonism/antagonism.

\subsection{Multitarget Drugs}

As cardiovascular diseases involve complex pathways, polypharmacology approaches can be a fruitful direction to tackle them [68]. Already, numerous multitarget drug molecules, following the molecular hybridization approach combining two discrete drugs in one molecule, have been designed and synthesized with beneficial effects. Some such examples are outlined below.

Mojarrad et al. [69], designed and synthesized molecules that combine structural elements present in $\mathrm{AT}_{1} \mathrm{R}$ antagonist and 1,4-dihydropyridine calcium channel blockers. Among the synthesized molecules, eight showed both calcium channel and AT 1 R blocking activities.

Interestingly, the effects of analogue $\mathbf{1 6}$ on $\mathrm{AT}_{1} \mathrm{R}$ were 100,000 higher than losartan (Figure 8). The experiments were conducted using aortic rings contracted by Ang II. The relaxant effects were measured and compound 16 had pD2 value 100,000 times higher (losartan pD2 $=-5.66 \pm 0.16$ and $16-10.52 \pm 0.18)[70]$.

Compounds 17 and 18 (Figure 9) exert potent dual activity, $\mathrm{AT}_{1} \mathrm{R}$ antagonism and partial proliferator-activated receptor- $\gamma(\operatorname{PPAR} \gamma)$ agonism and have desirable ADME properties [71,72].

A series of nitric oxide donating derivatives of [1,2,4]triazol-5(4H)-one exert both high $\mathrm{AT}_{1} \mathrm{R}$ antagonist activity and good maximum NO release [73]. The synthesis of the most promising compound 19 is outlined in Scheme 11. 


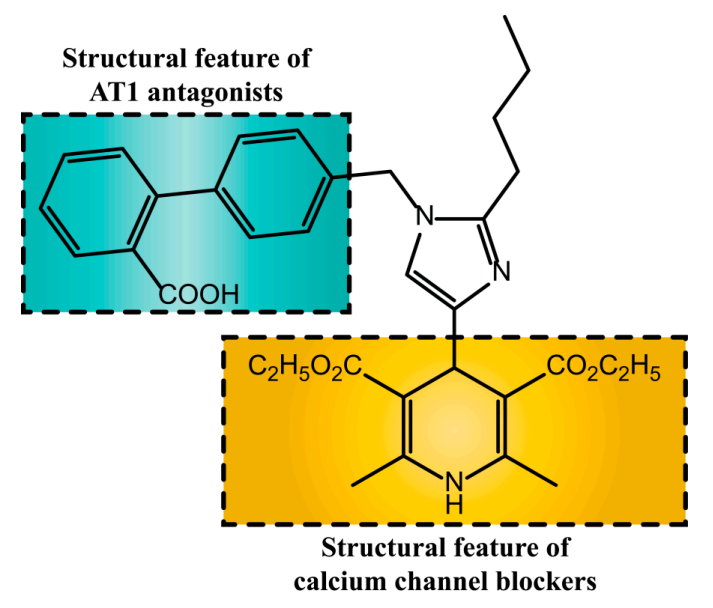

16

Figure 8. Compound $\mathbf{1 6}$ was designed with structural features to act as $\mathrm{AT}_{1} \mathrm{R}$ antagonist and calcium channel blocker.
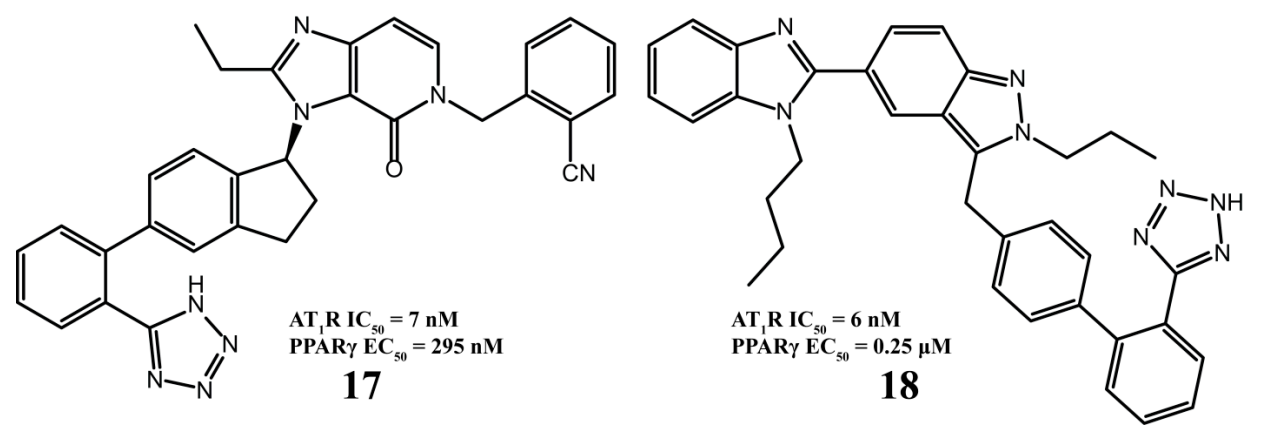

Figure 9. Molecules designed to act as $\mathrm{AT}_{1} \mathrm{R}$ antagonists and partial PPAR- $\gamma$ agonists. Activation of human PPAR $\gamma$ was evaluated using a chimeric receptor PPAR $\gamma$ Ligand Binding Domain (LBD)/Gal4 DNA Binding Domain while the activation of human recombinant $\mathrm{AT}_{1} \mathrm{R}$ was determined in a competition radioligand binding assay with $\left[{ }^{125} \mathrm{I}\right] \mathrm{Tyr}^{4}-\mathrm{Sar}^{1}, \mathrm{Ile}^{8}-$ Ang II.

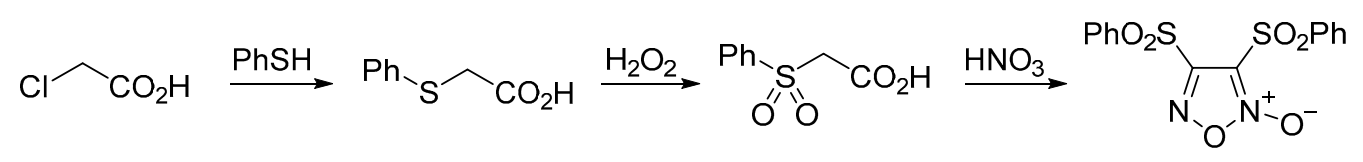

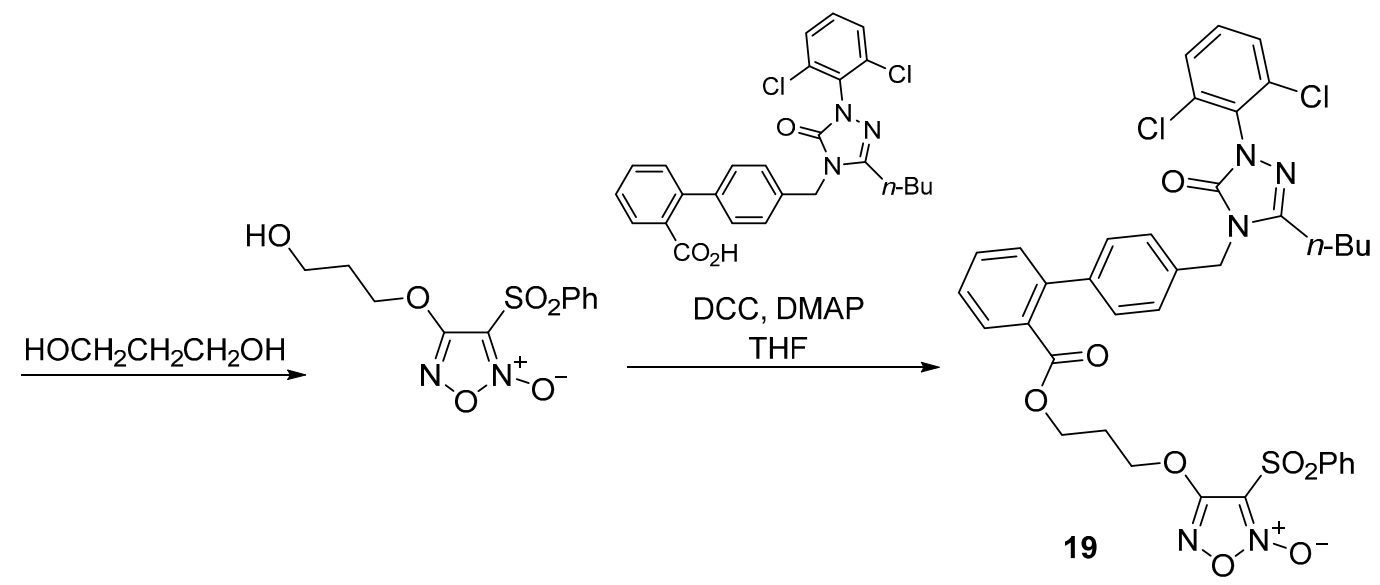

Scheme 11. Outline of the synthesis of compound 19. 
A very interesting chapter has been written by Murugesan describing the design of novel dual angiotensin II and endothelin receptor type A (ETA) antagonists [74]. Since both Ang II and endothelin I increase the blood pressure (the first acting in the AT 1 R and the other on the ETA) a blockade of both pathways could lead to a more effective reduction of blood pressure.

Multitarget drugs will certainly continue to be an interesting and fruitful approach and potentially can lead to more beneficial drugs with fewer side effects. At the moment only the structural requirements for $\mathrm{AT}_{1} \mathrm{R}$ antagonism are utilized. A deeper knowledge on the molecular determinants on the $\mathrm{AT}_{2} \mathrm{R}$ agonism and antagonism in the future will offer to medicinal chemists enhanced versatility towards the design and synthesis of new generation of more potent compounds.

\subsection{Molecular Modeling}

Ohmo et al. [75] demonstrated a unique binding mode of telmisartan to $\mathrm{AT}_{1} \mathrm{R}$. In particular, it was shown that telmisartan firmly binds to the $\mathrm{AT}_{1} \mathrm{R}$ through a unique shape that resembles the Greek letter delta $(\Delta)$ and it locks favorably at the receptor (delta lock), which may explain its superiority to other $\mathrm{ARBs}$ in halting cardiovascular diseases in patients with hypertension. The $\mathrm{AT}_{1} \mathrm{R}$ was modeled using the bovine rhodopsin crystal structure as a template and the docking program GOLD.

Kritsi et al. [76] using NMR spectroscopy, molecular modeling and Differential Scanning Calorimetry) (DSC) illustrated that telmisartan adopted a unique fingerprint in terms of its receptor interactions combined with the bilayer effects in comparison to other $\mathrm{AT}_{1} \mathrm{R}$ antagonists.

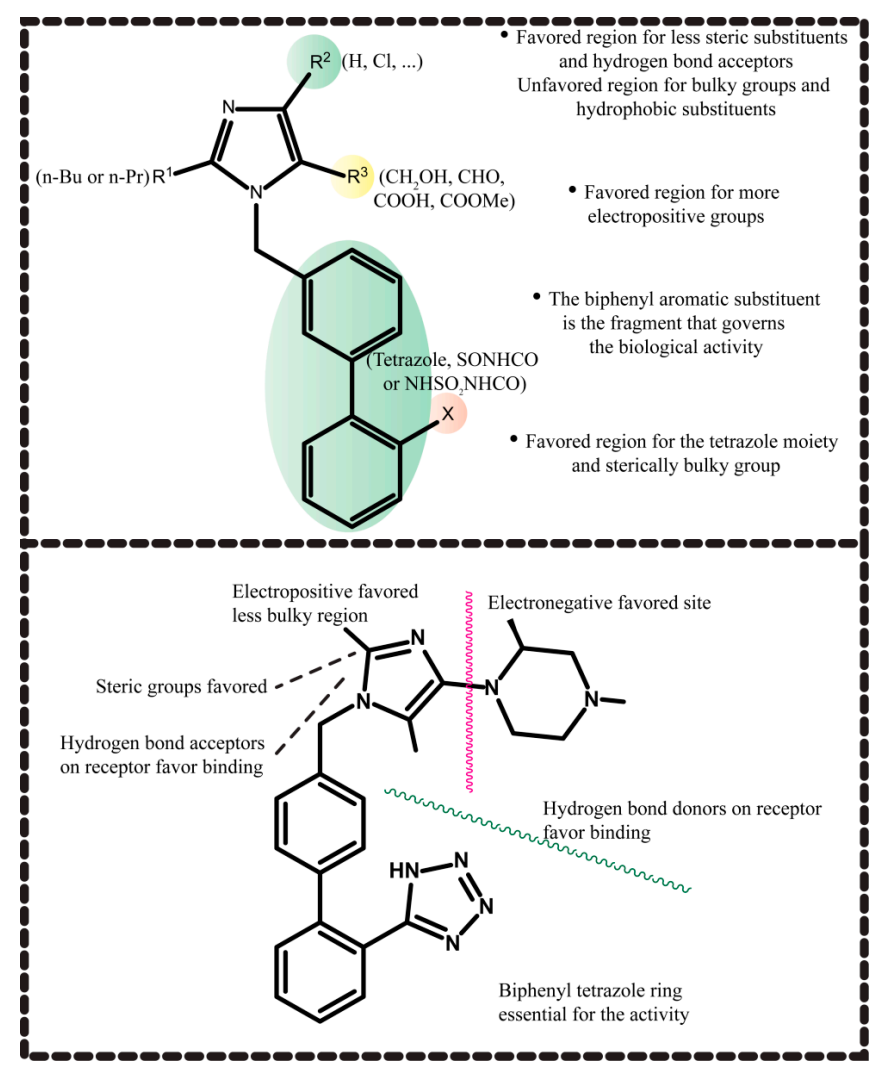

Figure 10. Requirements for $A T_{1} R$ antagonism as are depicted by the series of compounds used by Sharma et al. using descriptor optimization, PLSR and KNN-HFA analysis as well as 2D G-QSAR and 3D QSAR studies. 
Stepwise and simulated annealing were applied for descriptor optimization while PLSR and KNN-HFA analysis were used for 2D, G-QSAR and 3D-QSAR model development on acyl sulfonamides and acyl sulfamides derivatives of imidazole [77]. The major conclusions of this study are outlined in Figure 10. Sharma et al. [78-80] also published a series of articles in which QSAR models are constructed and evaluated.

Vyas et al. [81] designed novel substituted benzimidazole derivatives that serve as $\mathrm{AT}_{1} \mathrm{R}$ antagonists based on CoMFA and CoMSIA studies and in silico pharmacokinetic properties and toxicities. The most promising features for drug activity of this series of compounds are shown in Figure 11. Among the molecules they designed, they synthesized the two most promising. The synthesis of the most potent of the two, which possessed effects comparable with telmisartan, is outlined in Scheme 12. Compound 20 was evaluated using isolated rat aortic ring to determine its activity to competitively inhibit Ang II binding to $\mathrm{AT}_{1} \mathrm{R}$. The antagonistic activity, expressed as pA2 values, was $7.1 \pm 0.31$ for compound $\mathbf{2 0}$ and $7.5 \pm 0.29$ for telmisartan.

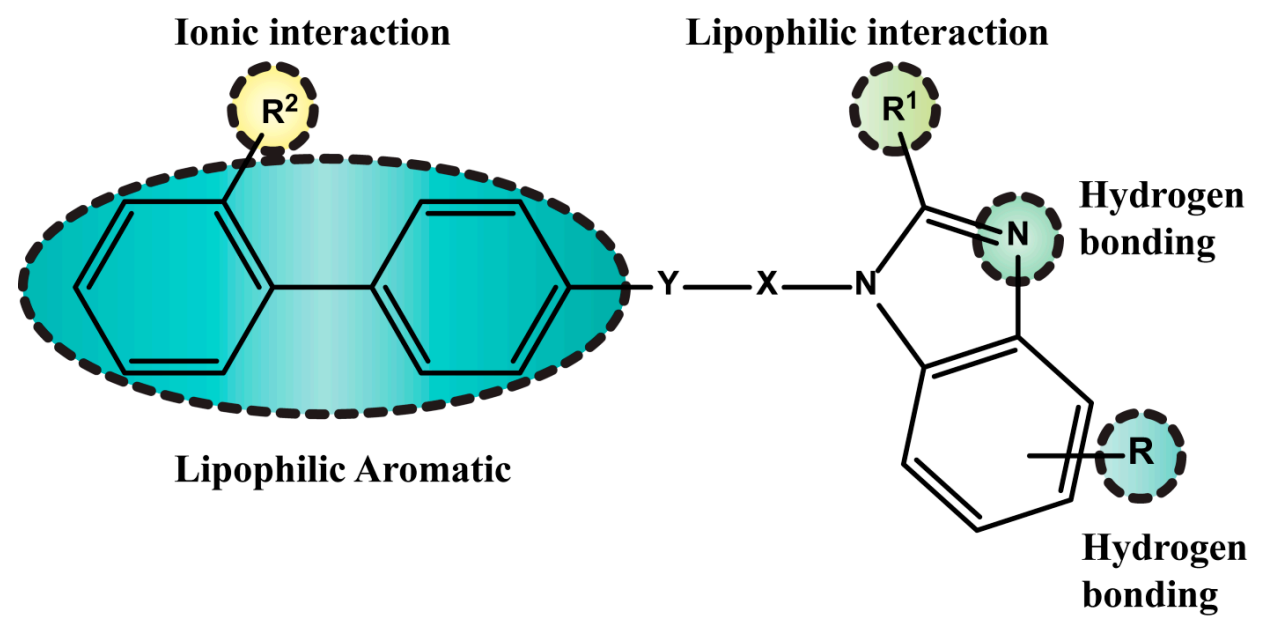

Figure 11. Important structural features for $A T_{1} R$ antagonism in the molecules studied by Vyas et al. using CoMFA and CoMSIA studies.<smiles>CCCCc1nc2cc([N+](=O)[O-])ccc2[nH]1</smiles><smiles>CCCCc1nc2cc([N+](=O)[O-])ccc2n1Cc1ccc(-c2ccccc2-c2nnn[nH]2)cc1</smiles>

Scheme 12. The steps involved in the synthesis of $\mathbf{2 0}$ using as starting material 4-nitrobenzene-1,2-diamine. 
Singh et al. [82] applied molecular modeling approach combining quantum-polarized ligand docking (QPLD), MM/GBSA free-energy calculation and 3D-QSAR analysis to evaluate 24 compounds as dual $\mathrm{AT}_{1} \mathrm{R}$ and ETA antagonists and to reveal their binding modes and structural basis of the inhibitory activity. Pharmacophore-based virtual screening and docking studies led to five lead compounds (Figure 12) that are possible potent dual antagonists [82].

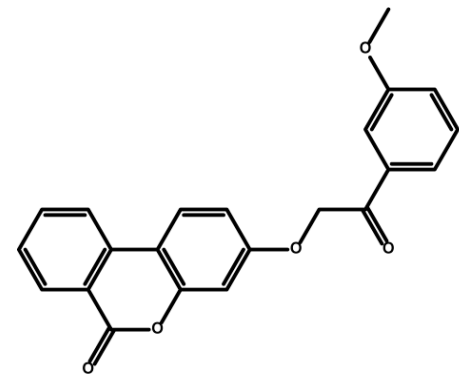

Lead 1

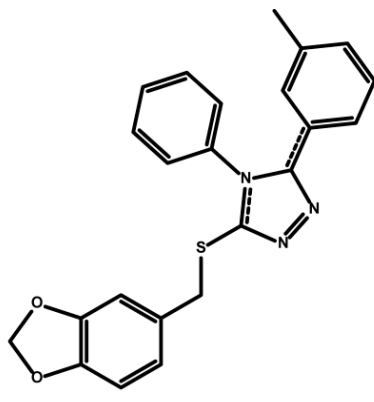

Lead 2

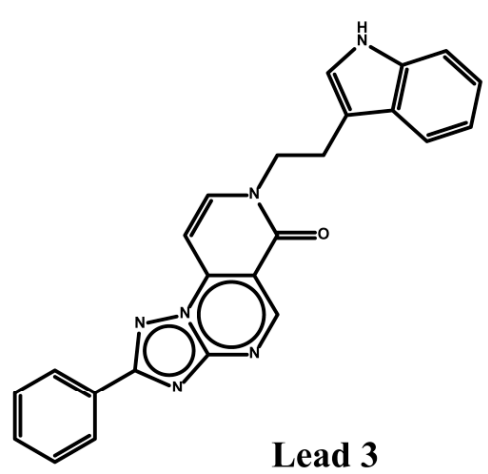

Lead 3

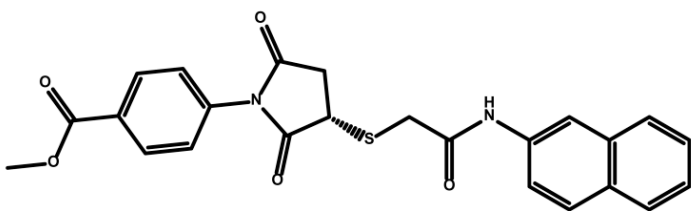

Lead 4

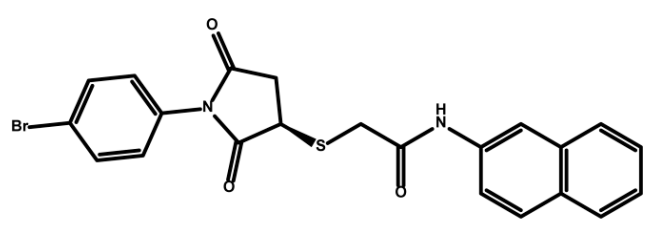

Lead 5

Figure 12. Five leads acting both at $A T_{1} \mathrm{R}$ and ETA receptors using molecular modeling approach combining quantum-polarized ligand docking (QPLD), MM/GBSA free-energy calculation and 3D-QSAR analysis.

Silva et al. [83] applied docking and CoMFA studies on $\mathrm{AT}_{1} \mathrm{R}$ antagonists. The obtained model enables the design of new bioactive compounds with optimized pharmacological /biological properties.

Fimasartan, (Figure 3) a derivative of losartan $\left(\mathrm{IC}_{50}=0.16 \mathrm{nM} \mathrm{AT}_{1} \mathrm{R}\right.$ and selectivity index for $\mathrm{AT}_{1} \mathrm{R}$ over $\mathrm{AT}_{2} \mathrm{R}=431,250$ ) was approved for the treatment of hypertension by the Korean Food and Drug Administration in September 2010. 3D-QSAR studies were performed by Choi et al. [84] to guide the design of backups (derivatives of fimasartan that lack its side effects), in the case of unexpected side effects during phase 4 trials.

Sköld et al. [85] explored the binding modes of Ang II and some pseudopeptide analogues at $\mathrm{AT}_{2} \mathrm{R}$ and found two plausible binding modes in agreement with most of the suggested ligand-receptor contact points reported in the literature. Docking calculations, using MacroModel's Monte Carlo multiple search minimum, showed that the ionic bridge between Phe ${ }^{8}$ (carboxyl) of Ang II and Lys 215 $\left(\mathrm{AT}_{1} \mathrm{R}\right)$ occurred most frequently in the ligand-receptor configurations. The contact between $\mathrm{His}^{6}$ (Ang II)-Asp279 (AT 1 R) and $\operatorname{Arg}^{2}$ (Ang II)-Asp297 (AT 1 R) and the contact of the $\mathrm{Tyr}^{4}$ residue of Ang II with Asp279 $\left(\mathrm{AT}_{1} \mathrm{R}\right)$ were among the most frequently observed.

Without doubt the pharmacophore approach, the use of molecular dynamics and calculation of thermodynamic parameters as well as 3D QSAR studies will lead to a better understanding of the structural requirements for the two Ang II receptors. At the moment the 3D QSAR studies are restrained mainly to $\mathrm{AT}_{1} \mathrm{R}$ and $\mathrm{AT}_{2} \mathrm{R}$. However, this approach has to be extended to multitargeting since beneficial molecules have already been synthesized. 


\subsection{Mechanisms of Activation of $A T_{1} R$ and $A T_{2} R$ and Signalling}

A recent review by Saku et al. [86] discusses the progress in the understanding of the molecular mechanism of $A_{1} T_{1} R$ and $A_{2} R$. The new scientific evidence according to the authors may lead to more selective therapeutic agents i.e., inhibit $\mathrm{AT}_{1} \mathrm{R}$ function such as cell signaling, inhibit homo-dimerization, or overexpress $\mathrm{AT}_{2} \mathrm{R}$-induced $\mathrm{AT}_{1} \mathrm{R}$ antagonism. A recent review by Akazama et al. [87] describes the progress in the receptor activation and signaling.

Matsoukas et al. [88,89] performed MD simulations with the $\mathrm{AT}_{1} \mathrm{R}$-Ang II-lipids complex and observed a series of dynamic changes in the topology of Ang II and the intracellular part of the receptor. Complete binding profiles of Ang II to the $\mathrm{AT}_{1} \mathrm{R}$, as well as the key transitional elements of the receptor and the agonist peptide upon activation through NMR and in silico studies were revealed. In addition, the use of a combination of computer simulations, including pharmacophore modeling, docking, molecular dynamics simulations with explicit inclusion of the membrane and ligand binding free energy calculations, permitted to propose the molecular mechanisms by which sartans interact with $\mathrm{AT}_{1} \mathrm{R}$ [89]. Sokkar et al. [90] claimed that multiple template-based homology modeling outweighs other methods for AT 1 R modeling.

Prokop et al. [91] proposed a new model of Ang II peptide binding to AT 1 R that correlates data from site directed mutagenesis and photolabeled experiments that were previously considered conflicting. Ang II binds $\mathrm{AT}_{1} \mathrm{R}$ and $\mathrm{AT}_{2} \mathrm{R}$ through a conserved initial binding mode involving amino acid Asn111 (consensus 325) of $\mathrm{AT}_{1} \mathrm{R}$ interacting with $\mathrm{Tyr}^{4}$ of Ang II and Lys199 and His256 (consensus 512 and 621) interacting with $\mathrm{Phe}^{8}$ of Ang II [91]. In both $\mathrm{AT}_{1} \mathrm{R}$ and $\mathrm{AT}_{2} \mathrm{R}$, the Ang II peptide may internalize through $\mathrm{Phe}^{8}$ of Ang II propagating through the receptors' conserved aromatic amino acids to the final photolabeled positioning relative to either $\mathrm{AT}_{1} \mathrm{R}$ at amino acid Asn294 (consensus 725) or $\mathrm{AT}_{2} \mathrm{R}$ at amino acid Leu138 (consensus 336). The authors conclude that understanding receptor activation provides valuable information for drug design and identification of other receptors that can potentially bind Ang II peptides [91].

A unique chemoselective photoaffinity labeling strategy, the methionine proximity assay (MPA), was used by Fillion et al. [92] to directly identify at physiological conditions a total of 38 discrete ligand/receptor contact residues that form the extracellular peptide-binding site of the activated $\mathrm{AT}_{1} \mathrm{R}$. This experimental data set was used in homology modeling to guide the positioning of the Ang II peptide within several GPCR crystal structure templates. The CX-C chemokine receptor type 4 (CXCR4) accommodated the results better than the others templates evaluated; a $\beta$-hairpin fold in extracellular loop (ECL) 2, in conjunction with two extracellular disulfide bridges, appeared to open and shape the entrance of the ligand-binding site. The bound Ang II adopted a somewhat vertical binding mode allowing concomitant contacts across the extracellular surface and deep within the transmembrane domains (TMD) core of the receptor. The authors proposed that such a dualistic nature of GPCR interaction could be well suited for diffusible linear peptide ligands and a common feature of other peptidergic class A GPCRs [92]. Balakumar et al. [93] recently published a review article describing the structural and functional characteristics of Ang II and its analogues and antagonists and their interactions with amino residues in the $\mathrm{AT}_{1} \mathrm{R}$.

Xie et al. [94] used the latest reported homologous chemokine receptors (PDB ID: 3ODU, 3OE0 and 3OE6) as templates to generate twenty models of $\mathrm{AT}_{1} \mathrm{R}$ receptor by multiple templates homology 
modeling. The docking results revealed that model 0020 possessed good affinities with these docked ARBs which are in accordance with both the $\mathrm{IC}_{50}$ inhibitor values and their curative effects. The results also showed more potent interactions between the model 0020 and its ARBs than those of ever reported results, such as hydrogen bonds, hydrophobic interactions, and especially cation- $\pi$ interactions and $\pi-\pi$ interactions. The authors, hypothesize that the structure of the model 0020 is quite close to its real crystal structure and the model 0020 may have the potential to be used for structure based drug design [94].

\subsection{The Role of Membrane Bilayers in the Binding to AT Receptors}

$\mathrm{AT}_{1} \mathrm{R}$ antagonists act on the transmembrane region of the receptor site while Ang II interacts with both extracellular and intracellular site. The way that $\mathrm{AT}_{1} \mathrm{R}$ antagonists interact with their active site, however, remains uncharted. Do they directly approach the receptor or are they intercalated into the membrane core and then diffuse to the active site of the receptor (Figure 13B) How crucial is the membrane bilayer core for their action? Drug-membrane interactions along with drug-AT $\mathrm{T}_{1}$ interactions are investigated to dissect the roles of these two components. The drug-membrane interactions show subtle but distinct differences between the thermal and dynamic properties of $\mathrm{AT}_{1} \mathrm{R}$ antagonists. The data suggest that each $\mathrm{AT}_{1} \mathrm{R}$ antagonist has a unique action on the membrane [95-107]. In the following figure, the interactions of candesartan cilexetil and olmesartan are illustrated as revealed from a combination of NMR spectroscopy, molecular modeling, Raman spectroscopy and Differential Scanning Calorimetry [108]. The study of the mechanism of losartan as it embeds in the lipid bilayers and approaches the $\mathrm{AT}_{1} \mathrm{R}$ has been recently studied [109]. Further work is needed to elaborate the issue of the preference of losartan into the two sites by using new models of $\mathrm{AT}_{1} \mathrm{R}$ as the one described by Matsoukas [89]. In our recent study, the application of 2D NOESY experiment led to the finding of the localization of $\mathrm{AT}_{1} \mathrm{R}$ antagonists (Figure 13A).

Molecular modeling enhances and promotes the field since it offers a better understanding of the interactions of drugs with $\mathrm{AT}_{1} \mathrm{R}$ and $\mathrm{AT}_{2} \mathrm{R}$. The non-crystallized receptors demand the use of modeling to generate $3 \mathrm{D}$ low energy conformers of $\mathrm{AT}_{1} \mathrm{R}$ and $\mathrm{AT}_{2} \mathrm{R}$. New approaches in the modeling of these receptors have recently been reported. Molecular Dynamics simulations are used to differentiate between the two step mechanism for drugs to reach the transmembrane active site of AT $\mathrm{A}_{1} \mathrm{R}$. The role of lipid bilayers in the $\mathrm{AT}_{1} \mathrm{R}$ antagonism is also studied using various biophysical methods.

\section{Future Perspectives}

The renin-angiotensin system is crucial for disease pathogenesis and cardiovascular control having as key players $\mathrm{AT}_{1} \mathrm{R}$ and $\mathrm{AT}_{2} \mathrm{R}$. Recent studies provided evidence that these two receptors, besides their known implication in blood pressure regulation and hemodynamics, are actively participating in numerous other processes independent from hemodynamic effects. For instance the role of $\mathrm{AT}_{1} \mathrm{R}$ to promote aging has been recently described, suggesting potential benefits of $\mathrm{AT}_{1} \mathrm{R}$ antagonists to promote longevity [110]. Also $\mathrm{AT}_{1} \mathrm{R}$ antagonists are effective in reducing inflammation and autoimmunity in rheumatic diseases [111] and bear antitumor properties [15]. Concerning the function of the $\mathrm{AT}_{2} \mathrm{R}$, this has been challenging owing to its low levels of expression and the limited availability of selective compounds targeting this receptor. Numerous literature evidence that the $\mathrm{AT}_{2} \mathrm{R}$ 
is strongly upregulated in cases of tissue damage such as myocardial infraction, brain ischemia, neuronal and vascular injury, highlights the high therapeutical potential of the $\mathrm{AT}_{2} \mathrm{R}$ in tissue protection and regeneration through regulating inflammation, fibrosis and apoptosis [56]. New results bring to light the beneficial effects of $\mathrm{AT}_{2} \mathrm{R}$ stimulation such as the protection of the myelin sheath in autoimmune central nervous system inflammation [112], inhibition of breast carcinoma cellular proliferation [26] and induction of analgesia [113]. Furthermore, not only the stimulation but also the inhibition of the $\mathrm{AT}_{2} \mathrm{R}$ is beneficial since very recently it was reported that the orally administered and highly selective $\mathrm{AT}_{2} \mathrm{R}$ antagonist EMA401 could be a novel treatment for postherpetic neuralgia [36].

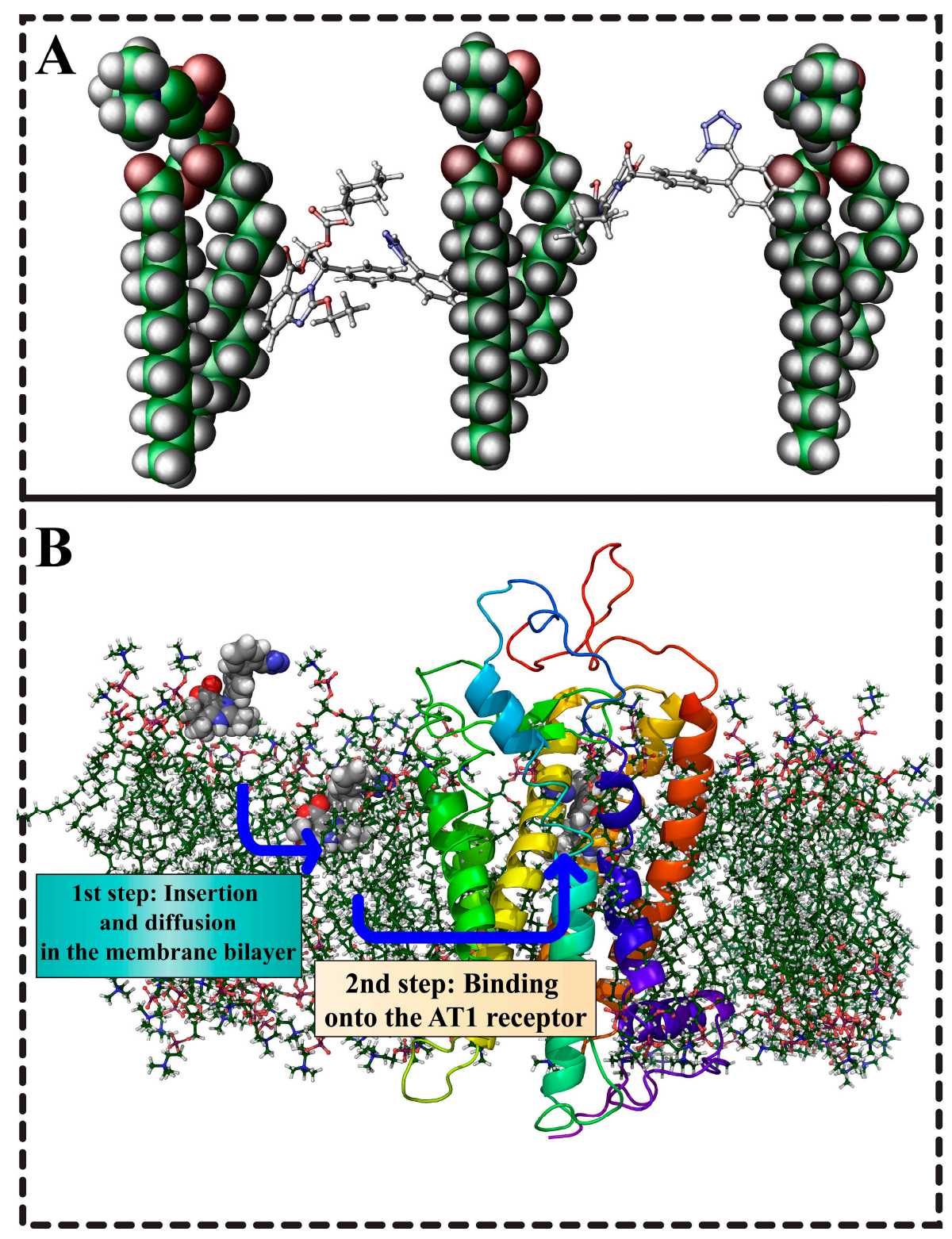

Figure 13. (A) candesartan cilexetil (left) and olmesartan (right) positioned in one leaflet of membrane bilayers. As it can be observed candesartan cilexetil is positioned deeper in membrane bilayers owing to its more hydrophobic nature. However, both molecules as they are amphipathic adopt polar and non-polar interactions. (B) Two step mechanism of action for ARBs. In the first step ARBs are postulated to embed themselves in the lipid matrix and in the second step are laterally diffused to the active site of $\mathrm{AT}_{1} \mathrm{R}$. 
These new findings highlight the need to develop novel and selective $A_{1} R$ and $A T_{2} R$ analogues. Screening the recent literature for covering the design and synthesis of $A_{1} R$ and $A T_{2} R$ ligands it has become evident that this field is not saturated and more effort is required to produce compounds bearing enhanced selectivity, potency and therapeutic efficacy. Still, there is no consensus of which model of the reported $\mathrm{AT}_{1} \mathrm{R}$ and $\mathrm{AT}_{2} \mathrm{R}$ has to be used by the medicinal chemists for the rational structure-based design and discovery of new selective drugs. It appears that the only solution to this problem will be the achievement of acquiring high resolution X-ray structures of these two receptors. Meanwhile, a significant effort must be made by the modelers to decide which model simulates more the biological one. The rationale used for the modelers is that docking and or molecular dynamics results should parallel the biological results. However, this has been claimed to exist for not only a unique model. This may reflect to the similarities of the proposed models.

Independently of the created models of the receptors, the synthetic chemists proceed with new ideas of synthesizing novel molecules. Indeed, these ideas were fruitful and bioactive molecules acting as $\mathrm{AT}_{2} \mathrm{R}$ agonists are already a reality. This effort to synthesize more selective drugs will certainly be continued. Another research activity which appears promising in the future is the synthesis of molecular hybrids and multitarget drugs. Due to the complexity of the systems that are involved in the cardiovascular diseases and others related to $\mathrm{AT}_{1} \mathrm{R}$ and $\mathrm{AT}_{2} \mathrm{R}$ the use of multitarget drugs will lead to beneficial aspects for treating these diseases avoiding in the same time side-effects.

\section{Acknowledgments}

This project has been co-financed by the European Union (European Regional Development FundERDF) and Greek national funds through the Operational Program "THESSALY-MAINLAND GREECE AND EPIRUS-2007-2013” of the National Strategic Reference Framework (NSRF 2007-2013).

\section{Author Contributions}

The three co-authors have equally contributed in writing the material of the manuscript and T. Mavromoustakos had also the general supervision.

\section{Conflicts of Interest}

The authors declare no conflict of interest.

\section{References}

1. De Gasparo, M.; Catt, K.J.; Inagami, T.; Wright, J.W.; Unger, T. International union of pharmacology. XXIII. The angiotensin II receptors. Pharmacol. Rev. 2000, 52, 415-472.

2. Burnier, M.; Brunner, H.R. Comparative antihypertensive effects of angiotensin II receptor antagonists. J. Am. Soc. Nephrol. 1999, 10, S278-S282.

3. Wood, J.M.; Maibaum, J.; Rahuel, J.; Grütter, M.G.; Cohen, N.C.; Rasetti, V.; Rüger, H.; Göschke, R.; Stutz, S.; Fuhrer, W.; et al. Structure-based design of aliskiren, a novel orally effective renin inhibitor. Biochem. Biophys. Res. Commun. 2003, 308, 698-705. 
4. Unger, T.; Chung, O.; Csikos, T.; Culman, J.; Gallinat, S.; Gohlke, P.; Hohle, S.; Meffert, S.; Stoll, M.; Stroth, U.; et al. Angiotensin receptors. J. Hypertens. Suppl. 1996, 14, S95-S103.

5. Swindle, J.D.; Santos, K.L.; Speth, R.C. Pharmacological characterization of a novel non-AT1, non-AT2 angiotensin binding site identified as neurolysin. Endocrine 2013, 44, 525-531.

6. Wangler, N.J.; Santos, K.L.; Schadock, I.; Hagen, F.K.; Escher, E.; Bader, M.; Speth, R.C.; Karamyan, V.T. Identification of membrane-bound variant of metalloendopeptidase neurolysin (EC 3.4.24.16) as the non-angiotensin type 1 (non-AT A $_{1}$, non-AT 2 angiotensin binding site. J. Biol. Chem. 2012, 287, 114-122.

7. Speth, R.C.; Carrera, E.J.; Bretón, C.; Linares, A.; Gonzalez-Reiley, L.; Swindle, J.D.; Santos, K.L.; Schadock, I.; Bader, M.; Karamyan, V.T. Distribution of non-AT 1 , non-AT 2 binding of ${ }^{125}{ }_{\text {i-sarcosine, }}$ isoleucine $^{8}$ angiotensin ii in neurolysin knockout mouse brains. PLoS One 2014, 9, e105762.

8. Unger, T. The angiotensin type 2 receptor: Variations on an enigmatic theme. J. Hypertens. 1999, 17, 1775-1786.

9. Steckelings, U.M.; Rompe, F.; Kaschina, E.; Namsolleck, P.; Grzesiak, A.; Funke-Kaiser, H.; Bader, M.; Unger, T. The past, present and future of angiotensin II type 2 receptor stimulation. J. Renin Angiotensin Aldosterone Syst. 2010, 11, 67-73.

10. Alterman, M. Development of selective non-peptide angiotensin II type 2 receptor agonsists. J. Renin Angiotensin Aldosterone Syst. 2010, 11, 57-66.

11. Unger, T.; Dahlöf, B. Compound 21, the first orally active, selective agonist of the angiotensin type 2 receptor $\left(\mathrm{AT}_{2}\right)$ : Implications for $\mathrm{AT}_{2}$ receptor research and therapeutic potential. J. Renin Angiotensin Aldosterone Syst. 2010, 11, 75-77.

12. Stoll, M.; Steckelings, U.M.; Paul, M.; Bottari, S.P.; Metzger, R.; Unger, T. The angiotensin $\mathrm{AT}_{2}$-receptor mediates inhibition of cell proliferation in coronary endothelial cells. J. Clin. Investig. 1995, 95, 651-657.

13. Nouet, S.; Nahmias, C. Signal transduction from the angiotensin II $\mathrm{AT}_{2}$ receptor. Trends Endocrinol. Metab. 2000, 11, 1-6.

14. Li, P.; Kondo, T.; Numaguchi, Y.; Kobayashi, K.; Aoki, M.; Inoue, N.; Okumura, K.; Murohara, T. Role of bradykinin, nitric oxide, and angiotensin II type 2 receptor in imidapril-induced angiogenesis. Hypertension 2008, 51, 252-258.

15. Kim, S.; Toyokawa, H.; Yamao, J.; Satoi, S.; Yanagimoto, H.; Yamamoto, T.; Hirooka, S.; Yamaki, S.; Inoue, K.; Matsui, Y.; et al. Antitumor effect of angiotensin II type 1 receptor blocker losartan for orthotopic rat pancreatic adenocarcinoma. Pancreas 2014, 43, 886-890.

16. Peng, X.; Wang, F.; Li, L.; Bum-Erdene, K.; Xu, D.; Wang, B.; Sinn, A.A.; Pollok, K.E.; Sandusky, G.E.; Li, L.; et al. Exploring a structural protein-drug interactome for new therapeutics in lung cancer. Mol. BioSyst. 2014, 10, 581-591.

17. Chen, X.; Meng, Q.; Zhao, Y.; Liu, M.; Li, D.; Yang, Y.; Sun, L.; Sui, G.; Cai, L.; Dong, X. Angiotensin II type 1 receptor antagonists inhibit cell proliferation and angiogenesis in breast cancer. Cancer Lett. 2013, 328, 318-324.

18. Rhodes, D.R.; Ateeq, B.; Cao, Q.; Tomlins, S.A.; Mehra, R.; Laxman, B.; Kalyana-Sundaram, S.; Lonigro, R.J.; Helgeson, B.E.; Bhojani, M.S.; et al. Agtr1 overexpression defines a subset of breast cancer and confers sensitivity to losartan, an agtr1 antagonist. Proc. Natl. Acad. Sci. USA 2009, 106, 10284-10289. 
19. Azevedo, H.; Fujita, A.; Bando, S.Y.; Iamashita, P.; Moreira-Filho, C.A. Transcriptional network analysis reveals that $\mathrm{AT}_{1}$ and $\mathrm{AT}_{2}$ angiotensin II receptors are both involved in the regulation of genes essential for glioma progression. PLoS One 2014, 9, e110934.

20. Dhande, I.; Ma, W.; Hussain, T. Angiotensin AT2 receptor stimulation is anti-inflammatory in lipopolysaccharide-activated thp-1 macrophages via increased interleukin-10 production. Hypertens. Res. 2015, 38, 21-29.

21. Castoldi, G.; di Gioia, C.R.; Bombardi, C.; Maestroni, S.; Carletti, R.; Steckelings, U.M.; Dahlof, B.; Unger, T.; Zerbini, G.; Stella, A. Prevention of diabetic nephropathy by compound 21, selective agonist of angiotensin type 2 receptors, in zucker diabetic fatty rats. Am. J. Physiol. Renal Physiol. 2014, 307, F1123-F1131.

22. McCarthy, C.A.; Vinh, A.; Miller, A.A.; Hallberg, A.; Alterman, M.; Callaway, J.K.; Widdop, R.E. Direct angiotensin $\mathrm{AT}_{2}$ receptor stimulation using a novel $\mathrm{AT}_{2}$ receptor agonist, compound 21, evokes neuroprotection in conscious hypertensive rats. PLoS One 2014, 9, e95762.

23. Iwanami, J.; Mogi, M.; Tsukuda, K.; Jing, F.; Ohshima, K.; Wang, X.L.; Nakaoka, H.; Kan-no, H.; Chisaka, T.; Bai, H.Y.; et al. Possible synergistic effect of direct angiotensin II type 2 receptor stimulation by compound 21 with memantine on prevention of cognitive decline in type 2 diabetic mice. Eur. J. Pharmacol. 2014, 724, 9-15.

24. Namsolleck, P.; Boato, F.; Schwengel, K.; Paulis, L.; Matho, K.S.; Geurts, N.; Thone-Reineke, C.; Lucht, K.; Seidel, K.; Hallberg, A.; et al. AT2-receptor stimulation enhances axonal plasticity after spinal cord injury by upregulating bdnf expression. Neurobiol. Dis. 2013, 51, 177-191.

25. Kawabata, A.; Baoum, A.; Ohta, N.; Jacquez, S.; Seo, G.M.; Berkland, C.; Tamura, M. Intratracheal administration of a nanoparticle-based therapy with the angiotensin II type 2 receptor gene attenuates lung cancer growth. Cancer Res. 2012, 72, 2057-2067.

26. Magnani, F.; Pappas, C.G.; Crook, T.; Magafa, V.; Cordopatis, P.; Ishiguro, S.; Ohta, N.; Selent, J.; Bosnyak, S.; Jones, E.S.; et al. Electronic sculpting of ligand-gpcr subtype selectivity: The case of angiotensin II. ACS Chem. Biol. 2014, 9, 1420-1425.

27. Agelis, G.; Resvani, A.; Durdagi, S.; Spyridaki, K.; Tůmová, T.; Slaninová, J.; Giannopoulos, P.; Vlahakos, D.; Liapakis, G.; Mavromoustakos, T.; et al. The discovery of new potent non-peptide angiotensin II AT 1 receptor blockers: A concise synthesis, molecular docking studies and biological evaluation of N-substituted 5-butylimidazole derivatives. Eur. J. Med. Chem. 2012, 55, 358-374.

28. Kohara, Y.; Kubo, K.; Imamiya, E.; Wada, T.; Inada, Y.; Naka, T. Synthesis and angiotensin II receptor antagonistic activities of benzimidazole derivatives bearing acidic heterocycles as novel tetrazole bioisosteres. J. Med. Chem. 1996, 39, 5228-5235.

29. Cappelli, A.; Pericot Mohr Gl, G.; Gallelli, A.; Rizzo, M.; Anzini, M.; Vomero, S.; Mennuni, L.; Ferrari, F.; Makovec, F.; Menziani, M.C.; et al. Design, synthesis, structural studies, biological evaluation, and computational simulations of novel potent AT(1) angiotensin II receptor antagonists based on the 4-phenylquinoline structure. J. Med. Chem. 2004, 47, 2574-2586.

30. Hein, L.; Meinel, L.; Pratt, R.E.; Dzau, V.J.; Kobilka, B.K. Intracellular trafficking of angiotensin II and its $\mathrm{AT}_{1}$ and $\mathrm{AT}_{2}$ receptors: Evidence for selective sorting of receptor and ligand. Mol. Endocrinol. 1997, 11, 1266-1277.

31. Kaschina, E.; Unger, T. Angiotensin AT1/AT2 receptors: Regulation, signalling and function. Blood Press. 2003, 12, 70-88. 
32. Steckelings, U.M.; Kaschina, E.; Unger, T. The $\mathrm{AT}_{2}$ receptor-A matter of love and hate. Peptides 2005, 26, 1401-1409.

33. Dudley, D.T.; Panek, R.L.; Major, T.C.; Lu, G.H.; Bruns, R.F.; Klinkefus, B.A.; Hodges, J.C.; Weishaar, R.E. Subclasses of angiotensin II binding sites and their functional significance. Mol. Pharmacol. 1990, 38, 370-377.

34. Whitebread, S.E.; Taylor, V.; Bottari, S.P.; Kamber, B.; de Gasparo, M. Radioiodinated cgp 42112a: A novel high affinity and highly selective ligand for the characterization of angiotensin $\mathrm{AT}_{2}$ receptors. Biochem. Biophys. Res. Commun. 1991, 181, 1365-1371.

35. Wan, Y.; Wallinder, C.; Plouffe, B.; Beaudry, H.; Mahalingam, A.K.; Wu, X.; Johansson, B.; Holm, M.; Botoros, M.; Karlén, A.; et al. Design, synthesis, and biological evaluation, of the first selective nonpeptide $\mathrm{AT}_{2}$ receptor agonist. J. Med. Chem. 2004, 47, 5995-6008.

36. Rice, A.S.C.; Dworkin, R.H.; McCarthy, T.D.; Anand, P.; Bountra, C.; McCloud, P.I.; Hill, J.; Cutter, G.; Kitson, G.; Desem, N.; et al. Ema401, an orally administered highly selective angiotensin II type 2 receptor antagonist, as a novel treatment for postherpetic neuralgia: A randomised, double-blind, placebo-controlled phase 2 clinical trial. The Lancet 2014, 383, 1637-1647.

37. McCarthy, T. Development of ema401 as an orally-administered, highly-selective angiotensin II type 2 receptor antagonist for the treatment of neuropathic pain. J. Peripher. Nerv. Syst. 2014, 19, S13-S14.

38. Ichiki, T.; Labosky, P.A.; Shiota, C.; Okuyama, S.; Imagawa, Y.; Fogo, A.; Niimura, F.; Ichikawa, I.; Hogan, B.L.M.; Inagami, T. Effects on blood pressure and exploratory behaviour of mice lacking angiotensin II type-2 receptor. Nature 1995, 377, 748-750.

39. Rein, L.; Barsh, G.S.; Pratt, R.E.; Dzau, V.J.; Kobilka, B.K. Behavioural and cardiovascular effects of disrupting the angiotensin II type-2 receptor gene in mice. Nature 1995, 377, 744-747.

40. Speth, R.C.; Kim, K.H. Discrimination of two angiotensin II receptor subtypes with a selective agonist analogue of angiotensin II, p-aminophenylalanine6 angiotensin II. Biochem. Biophys. Res. Commun. 1990, 169, 997-1006.

41. Yoshikawa, M.; Ohinata, K.; Yamada, Y. The pharmacological effects of novokinin; a designed peptide agonist of the angiotensin $\mathrm{AT}_{2}$ receptor. Curr. Pharm. Des. 2013, 19, 3009-3012.

42. Guimond, M.O.; Hallberg, M.; Gallo-Payet, N.; Wallinder, C. Saralasin and sarile are $\mathrm{AT}_{2}$ receptor agonists. ACS Med. Chem. Lett. 2014, 5, 1129-1132.

43. Mavromoustakos, T.; Agelis, G.; Durdagi, S. AT 1 antagonists: A patent review (2008-2012). Expert Opin. Ther. Pat. 2013, 23, 1483-1494.

44. Naik, P.; Murumkar, P.; Giridhar, R.; Yadav, M.R. Angiotensin II receptor type 1 (AT 1 ) selective nonpeptidic antagonists-A perspective. Bioorg. Med. Chem. 2010, 18, 8418-8456.

45. Trstenjak, U.; Kikelj, D. Multitarget cardiovascular drugs. Curr. Med. Chem. 2011, 18, 2531-2542.

46. Tuccinardi, T.; Martinelli, A. Computational approaches on angiotensin receptors and their ligands: Recent developments and results. Curr. Med. Chem. 2007, 14, 3105-3121.

47. Agelis, G.; Resvani, A.; Koukoulitsa, C.; Tůmová, T.; Slaninová, J.; Kalavrizioti, D.; Spyridaki, K.; Afantitis, A.; Melagraki, G.; Siafaka, A.; et al. Rational design, efficient syntheses and biological evaluation of $N, N^{\prime}$-symmetrically bis-substituted butylimidazole analogs as a new class of potent angiotensin II receptor blockers. Eur. J. Med. Chem. 2013, 62, 352-370. 
48. Agelis, G.; Resvani, A.; Matsoukas, M.T.; Tselios, T.; Kelaidonis, K.; Kalavrizioti, D.; Vlahakos, D.; Matsoukas, J. Towards non-peptide ang II AT1 receptor antagonists based on urocanic acid: Rational design, synthesis and biological evaluation. Amino Acids 2011, 40, 411-420.

49. Agelis, G.; Resvani, A.; Ntountaniotis, D.; Chatzigeorgiou, P.; Koukoulitsa, C.; Androutsou, M.E.; Plotas, P.; Matsoukas, J.; Mavromoustakos, T.; Čendak, T.; et al. Interactions of the potent synthetic AT1 antagonist analog bv6 with membrane bilayers and mesoporous silicate matrices. BBA-Bioenergetics 2013, 1828, 1846-1855.

50. Deprez-Poulain, R.; Cousaert, N.; Toto, P.; Willand, N.; Deprez, B. Application of ullmann and ullmann-finkelstein reactions for the synthesis of $N$-aryl- $N$-(1H-pyrazol-3-yl) acetamide or $N$-(1aryl-1H-pyrazol-3-yl) acetamide derivatives and pharmacological evaluation. Eur. J. Med. Chem. 2011, 46, 3867-3876.

51. Zhang, J.; Wang, J.L.; Yu, W.F.; Zhou, Z.M.; Tao, W.C.; Wang, Y.C.; Xue, W.Z.; Xu, D.; Hao, L.P.; Han, X.F.; et al. Nonpeptidic angiotensin II AT1 receptor antagonists derived from 6-substituted aminocarbonyl and acylamino benzimidazoles. Eur. J. Med. Chem. 2013, 69, 44-54.

52. Da, Y.J.; Yuan, W.D.; Xin, T.; Nie, Y.Y.; Ye, Y.; Yan, Y.J.; Liang, L.S.; Chen, Z.L. Synthesis and biological evaluation of new fluorine substituted derivatives as angiotensin II receptor antagonists with anti-hypertension and anti-tumor effects. Bioorg. Med. Chem. 2012, 20, 7101-7111.

53. Zhu, W.; Da, Y.; Wu, D.; Zheng, H.; Zhu, L.; Wang, L.; Yan, Y.; Chen, Z. Design, synthesis and biological evaluation of new 5-nitro benzimidazole derivatives as $\mathrm{AT}_{1}$ antagonists with anti-hypertension activities. Bioorg. Med. Chem. 2014, 22, 2294-2302.

54. Ismail, M.A.H.; Aboul-Enein, M.N.; El-Azzouny, A.A.E.; Abouzid, K.A.M.; Ismail, N.S.M. Design, synthesis, and antihypertensive evaluation of 2'-tetrazolyl and 2'-carboxybiphenylylmethyl-pyrrolidine scaffolds substituted at their $\mathrm{N}_{1}, \mathrm{C}_{3}$, and $\mathrm{C}_{4}$ positions as potential angiotensin II AT 1 receptor antagonists. Med. Chem. Res. 2015, 24, 442-458.

55. Ismail, M.A.H.; Abou El Ella, D.A.; Abouzid, K.A.M.; Al-Ansary, G.H.A. Computer-based drug design, synthesis and biological evaluation of new pyrimidinone derivatives linked to arylpiperazine and 2'-carbethoxy-biphenylylmethyl moeities as $\alpha 1$-adrenoceptor antagonists and angiotensin II AT1 receptor antagonists. Pharmazie 2010, 65, 794-800.

56. Namsolleck, P.; Recarti, C.; Foulquier, S.; Steckelings, U.M.; Unger, T. AT2 receptor and tissue injury: Therapeutic implications. Curr. Hypertens. Rep. 2014, 16, 416.

57. Tamargo, J.; López-Sendón, J. Novel therapeutic targets for the treatment of heart failure. Nat. Rev. Drug Discov. 2011, 10, 536-555.

58. Wallinder, C.; Botros, M.; Rosenström, U.; Guimond, M.O.; Beaudry, H.; Nyberg, F.; Gallo-Payet, N.; Hallberg, A.; Alterman, M. Selective angiotensin II AT2 receptor agonists: Benzamide structure-activity relationships. Bioorg. Med. Chem. 2008, 16, 6841-6849.

59. Steckelings, U.M.; Larhed, M.; Hallberg, A.; Widdop, R.E.; Jones, E.S.; Wallinder, C.; Namsolleck, P.; Dahlöf, B.; Unger, T. Non-peptide AT2-receptor agonists. Curr. Opin. Pharm. 2011, 11, 187-192.

60. Wu, X.; Wan, Y.; Mahalingam, A.K.; Plouffe, B.; Botros, M.; Karlén, A.; Hallberg, M.; Gallo-Payet, N.; Alterman, M. Selective angiotensin II AT2 receptor agonists: Arylbenzylimidazole structure-activity relationships. J. Med. Chem. 2006, 49, 7160-7168. 
61. Liu, J.; Liu, Q.; Yang, X.; Xu, S.; Zhang, H.; Bai, R.; Yao, H.; Jiang, J.; Shen, M.; Wu, X.; et al. Design, synthesis, and biological evaluation of 1,2,4-triazole bearing 5-substituted biphenyl-2sulfonamide derivatives as potential antihypertensive candidates. Bioorg. Med. Chem. 2013, 21, 7742-7751.

62. Mahalingam, A.K.; Wan, Y.; Murugaiah, A.M.S.; Wallinder, C.; Wu, X.; Plouffe, B.; Botros, M.; Nyberg, F.; Hallberg, A.; Gallo-Payet, N.; et al. Selective angiotensin II AT2 receptor agonists with reduced cyp 450 inhibition. Bioorg. Med. Chem. 2010, 18, 4570-4590.

63. Murugaiah, A.M.S.; Wu, X.; Wallinder, C.; Mahalingam, A.K.; Wan, Y.; Sköld, C.; Botros, M.; Guimond, M.O.; Joshi, A.; Nyberg, F.; et al. From the first selective non-peptide at 2 receptor agonist to structurally related antagonists. J. Med. Chem. 2012, 55, 2265-2278.

64. Verdonk, K.; Durik, M.; Abd-Alla, N.; Batenburg, W.W.; van den Bogaerdt, A.J.; van Veghel, R.; Roks, A.J.; Danser, A.H.; van Esch, J.H. Compound 21 induces vasorelaxation via an endotheliumand angiotensin II type 2 receptor-independent mechanism. Hypertension 2012, 60, 722-729.

65. Veron, J.-B.; Joshi, A.; Wallinder, C.; Larhed, M.; Odell, L.R. Synthesis and evaluation of isoleucine derived angiotensin II AT2 receptor ligands. Bioorg. Med. Chem. Lett. 2014, 24, 476-479.

66. Georgsson, J.; Sköld, C.; Botros, M.; Lindeberg, G.; Nyberg, F.; Karlén, A.; Hallberg, A.; Larhed, M. Synthesis of a new class of druglike angiotensin II C-terminal mimics with affinity for the $\mathrm{AT}_{2}$ receptor. J. Med. Chem. 2007, 50, 1711-1715.

67. Behrends, M.; Wallinder, C.; Wieckowska, A.; Guimond, M.O.; Hallberg, A.; Gallo-Payet, N.; Larhed, M. $N$-aryl isoleucine derivatives as angiotensin II $\mathrm{AT}_{2}$ receptor ligands. ChemistryOpen 2014, 3, 65-75.

68. Janga, S.C.; Tzakos, A. Structure and organization of drug-target networks: Insights from genomic approaches for drug discovery. Mol. BioSyst. 2009, 5, 1536-1548.

69. Mojarrad, J.S.; Zamani, Z.; Nazemiyeh, H.; Ghasemi, S.; Asgari, D. Synthesis of novel 1,4-dihydropyridine derivatives bearing biphenyl-2'-tetrazole substitution as potential dual angiotensin II receptors and calcium channel blockers. Adv. Pharm. Bull. 2011, 1, 1-9.

70. Hadizadeh, F.; Imenshahidi, M.; Esmaili, P.; Taghiabadi, M. Synthesis and effects of novel dihydropyridines as dual calcium channel blocker and angiotensin antagonist on isolated rat aorta. Iranian J. Basic Med. Sci. 2010, 13, 195-201.

71. Casimiro-Garcia, A.; Heemstra, R.J.; Bigge, C.F.; Chen, J.; Ciske, F.A.; Davis, J.A.; Ellis, T.; Esmaeil, N.; Flynn, D.; Han, S.; et al. Design, synthesis, and evaluation of imidazo[4,5c]pyridin-4-one derivatives with dual activity at angiotensin II type 1 receptor and peroxisome proliferator-activated receptor- $\gamma$. Bioorg. Med. Chem. Lett. 2013, 23, 767-772.

72. Lamotte, Y.; Faucher, N.; Sançon, J.; Pineau, O.; Sautet, S.; Fouchet, M.H.; Beneton, V.; Tousaint, J.J.; Saintillan, Y.; Ancellin, N.; et al. Discovery of novel indazole derivatives as dual angiotensin II antagonists and partial ppary agonists. Bioorg. Med. Chem. Lett. 2014, 24, 1098-1103.

73. Zhang, Y.; Zhou, J.; Pan, W.; Wu, X.; Wang, S. Synthesis and biological study of 3-butyl-1-(2,6dichlorophenyl)- $1 H$-[1,2,4]triazol-5(4H)-one derivatives as anti-hypertension drugs. Lett. Drug Des. Discov. 2010, 7, 18-22.

74. Murugesan, N. Chapter 19 designing drugs with dual activity: Novel dual angiotensin II and endothelin receptor antagonists. In Designing Multi-Target Drugs; The Royal Society of Chemistry: Cambridge, UK, 2012; pp. 316-334. 
75. Ohno, K.; Amano, Y.; Kakuta, H.; Niimi, T.; Takakura, S.; Orita, M.; Miyata, K.; Sakashita, H.; Takeuchi, M.; Komuro, I.; et al. Unique "delta lock" structure of telmisartan is involved in its strongest binding affinity to angiotensin II type 1 receptor. Biochem. Biophys. Res. Commun. 2011, 404, 434-437.

76. Kritsi, E.; Potamitis, C.; Durdagi, S.; Zoumpoulakis, P.; Golic Grdadolnik, S.; Mavromoustakos, T. Molecular insights into the AT1 antagonism based on biophysical and in silico studies of telmisartan. Med. Chem. Res. 2013, 22, 4842-4857.

77. Sharma, M.C.; Sharma, S.; Sharma, P.; Kumar, A.; Bhadoriya, K.S. Structural insights for substituted acyl sulfonamides and acyl sulfamides derivatives of imidazole as angiotensin II receptor antagonists using molecular modeling approach. J. Taiwan Inst. Chem. E 2014, 45, 12-23.

78. Sharma, M.C.; Kohli, D.V. A comprehensive structure-activity analysis 2,3,5-trisubstituted 4,5-dihydro-4-oxo-3H-imidazo[4,5-c]pyridine derivatives as angiotensin II receptor antagonists: Using 2D- and 3D-QSAR approach. Med. Chem. Res. 2013, 22, 588-605.

79. Sharma, M.C.; Kohli, D.V. Comprehensive structure-activity relationship analysis of substituted 5-(biphenyl-4-ylmethyl)pyrazoles derivatives as AT1 selective angiotensin II receptor antagonists: 2D and KNNMFA QSAR approach. Med. Chem. Res. 2013, 22, 2124-2138.

80. Sharma, M.C.; Kohli, D.V. Predicting substituted 2-butylbenzimidazoles derivatives as angiotensin II receptor antagonists: 3D-QSAR and pharmacophore modeling. J. Saudi Chem. Soc. 2011, doi:10.1016/j.jscs.2011.09.001.

81. Vyas, V.K.; Gupta, N.; Ghate, M.; Patel, S. Design, synthesis, pharmacological evaluation and in silico admet prediction of novel substituted benzimidazole derivatives as angiotensin II-AT1 receptor antagonists based on predictive 3D QSAR models. SAR QSAR Environ. Res. 2014, 25, $117-146$.

82. Singh, K.D.; Muthusamy, K. Molecular modeling, quantum polarized ligand docking and structure-based 3D-QSAR analysis of the imidazole series as dual KT1 and ET a receptor antagonists. Acta Pharmacol. Sin. 2013, 34, 1592-1606.

83. Da C. Silva, D.; Maltarollo, V.G.; de Lima, E.F.; Weber, K.C.; Honorio, K.M. Understanding electrostatic and steric requirements related to hypertensive action of $\mathrm{AT}_{1}$ antagonists using molecular modeling techniques. J. Mol. Model. 2014, 20, 2231-2244.

84. Choi, M.J.; Kwon, G.H.; Han, N.S.; Yoo, B.W.; Kim, J.H.; Paik, S.H.; Chi, Y.H.; Lee, K.-T.; Lee, J.Y. Development of 3D-QSAR CoMSIA models for 5-(biphenyl-2-yl)-1H-tetrazole derivatives as angiotensin II receptor type 1 ( $\left.\mathrm{AT}_{1}\right)$ antagonists. Bioorg. Med. Chem. Lett. 2013, 23, 4540-4546.

85. Sköld, C.; Nikiforovich, G.; Karlén, A. Modeling binding modes of angiotensin II and pseudopeptide analogues to the AT2 receptor. J. Mol. Graphics Model. 2008, 26, 991-1003.

86. Miura, S.I.; Imaizumi, S.; Saku, K. Recent progress in molecular mechanisms of angiotensin II type 1 and 2 receptors. Curr. Pharm. Des. 2013, 19, 2981-2987.

87. Akazawa, H.; Yano, M.; Yabumoto, C.; Kudo-Sakamoto, Y.; Komuro, I. Angiotensin II type 1 and type 2 receptor-induced cell signaling. Curr. Pharm. Des. 2013, 19, 2988-2995.

88. Matsoukas, M.T.; Potamitis, C.; Plotas, P.; Androutsou, M.E.; Agelis, G.; Matsoukas, J.; Zoumpoulakis, P. Insights into $\mathrm{AT}_{1}$ receptor activation through ANGII binding studies. J. Chem. Inf. Model. 2013, 53, 2798-2811. 
89. Matsoukas, M.T.; Cordomí, A.; Ríos, S.; Pardo, L.; Tselios, T. Ligand binding determinants for angiotensin II type 1 receptor from computer simulations. J. Chem. Inf. Model. 2013, 53, 2874-2883.

90. Sokkar, P.; Mohandass, S.; Ramachandran, M. Multiple templates-based homology modeling enhances structure quality of $\mathrm{AT}_{1}$ receptor: Validation by molecular dynamics and antagonist docking. J. Mol. Model. 2011, 17, 1565-1577.

91. Prokop, J.W.; Santos, R.A.S.; Milsted, A. Differential mechanisms of activation of the ang peptide receptors AT1, AT2, and MAS: Using in silico techniques to differentiate the three receptors. PLoS One 2013, 8, e65307.

92. Fillion, D.; Cabana, J.; Guillemette, G.; Leduc, R.; Lavigne, P.; Escher, E. Structure of the human angiotensin II type $1\left(\mathrm{AT}_{1}\right)$ receptor bound to angiotensin II from multiple chemoselective photoprobe contacts reveals a unique peptide binding mode. J. Biol. Chem. 2013, 288, 8187-8197.

93. Balakumar, P.; Jagadeesh, G. Structural determinants for binding, activation, and functional selectivity of the angiotensin AT1 receptor. J. Mol. Endocrinol. 2014, 53, R71-R92.

94. Xie, Y.-F.; Jiang, Y.-R.; Pan, Y.-F.; Chen, D.; Li, C.-J. Multiple templates-based homology modeling and docking analysis of angiotensin II type 1 receptor. J. Cent. South. Univ. 2012, 19, 3033-3039.

95. Mavromoustakos, T.; Durdagi, S.; Koukoulitsa, C.; Simcic, M.; Papadopoulos, M.G.; Hodoscek, M.; Grdadolnik, S.G. Strategies in the rational drug design. Curr. Med. Chem. 2011, $18,2517-2530$.

96. Zoumpoulakis, P.; Mavromoustakos, T. Seeking the active site of the AT1 receptor for computational docking studies. Drug Design Reviews Online 2005, 2, 537-545.

97. Mavromoustakos, T.; Zervou, M.; Zoumpoulakis, P.; Kyrikou, I.; Benetis, N.P.; Polevaya, L.; Roumelioti, P.; Giatas, N.; Zoga, A.; Moutevelis Minakakis, P.; et al. Conformation and bioactivity. Design and discovery of novel antihypertensive drugs. Curr. Top. Med. Chem. 2004, 4, 385-401.

98. Mavromoustakos, T.M.; Zervou, M.V.; Zoumpoulakis, P.G. Design and discovery of novel antihypertensive drugs through conformation and bioactivity studies. In Frontiers in Medicinal Chemistry; Atta-Ur-Rahman, Reitz, A.B., Eds.; Bentham Science Publishers: Sharjah, UAE, 2006; Volume 3, pp. 87-111.

99. Mavromoustakos, T.; Zoumpoulakis, I.; Kyrikou, I.; Zoga, A.; Siapi, E.; Zervou, M.; Daliani, I.; Dimitriou, D.; Pitsas, A.; Kamoutsis, C.; et al. Efforts to understand the molecular basis of hypertension through drug: Membrane interactions. Curr. Top. Med. Chem. 2004, 4, 445-459.

100. Fotakis, C.; Megariotis, G.; Christodouleas, D.; Kritsi, E.; Zoumpoulakis, P.; Ntountaniotis, D.; Zervou, M.; Potamitis, C.; Hodzic, A.; Pabst, G.; et al. Comparative study of the AT1 receptor prodrug antagonist candesartan cilexetil with other sartans on the interactions with membrane bilayers. BBA-Bioenergetics 2012, 1818, 3107-3120.

101. Hodzic, A.; Zoumpoulakis, P.; Pabst, G.; Mavromoustakos, T.; Rappolt, M. Losartan's affinity to fluid bilayers modulates lipid-cholesterol interactions. PCCP 2012, 14, 4780-4788.

102. Ntountaniotis, D.; Mali, G.; Grdadolnik, S.G.; Maria, H.; Skaltsounis, A.L.; Potamitis, C.; Siapi, E.; Chatzigeorgiou, P.; Rappolt, M.; Mavromoustakos, T. Thermal, dynamic and structural properties of drug AT1 antagonist olmesartan in lipid bilayers. BBA-Bioenergetics 2011, 1808, 2995-3006. 
103. Fotakis, C.; Christodouleas, D.; Zoumpoulakis, P.; Kritsi, E.; Benetis, N.P.; Mavromoustakos, T.; Reis, H.; Gili, A.; Papadopoulos, M.G.; Zervou, M. Comparative biophysical studies of sartan class drug molecules losartan and candesartan (CV-11974) with membrane bilayers. J. Phys. Chem. B 2011, 115, 6180-6192.

104. Potamitis, C.; Chatzigeorgiou, P.; Siapi, E.; Viras, K.; Mavromoustakos, T.; Hodzic, A.; Pabst, G.; Cacho-Nerin, F.; Laggner, P.; Rappolt, M. Interactions of the AT1 antagonist valsartan with dipalmitoyl-phosphatidylcholine bilayers. BBA-Bioenergetics 2011, 1808, 1753-1763.

105. Mavromoustakos, T.; Chatzigeorgiou, P.; Koukoulitsa, C.; Durdagi, S. Partial interdigitation of lipid bilayers. Int. J. Quantum Chem. 2011, 111, 1172-1183.

106. Fotakis, C.; Gega, S.; Siapi, E.; Potamitis, C.; Viras, K.; Moutevelis-Minakakis, P.; Kokotos, C.G.; Durdagi, S.; Grdadolnik, S.G.; Sartori, B.; et al. Interactions at the bilayer interface and receptor site induced by the novel synthetic pyrrolidinone analog MMK3. BBA-Bioenergetics 2010, 1798, $422-432$.

107. Mavromoustakos, T.; Golic Grdadolnik, S.; Zervou, M.; Zoumpoulakis, P.; Potamitis, C.; Politi, A.; Mantzourani, E.; Platts, J.A.; Koukoulitsa, C.; Minakakis, P.; et al. Putative bioactive conformers of small molecules: A concerted approach using NMR spectroscopy and computational chemistry. In Medicinal Chemistry Research Progress, Ricci, S., Colombo, G.P., Eds.; Nova Science Publishers: New York, NY, USA, 2008; pp. 175-207.

108. Ntountaniotis, D.; Kellici, T.; Tzakos, A.; Kolokotroni, P.; Tselios, T.; Becker-Baldus, J.; Glaubitz, C.; Lin, S.; Makriyannis, A.; Mavromoustakos, T. The application of solid-state NMR spectroscopy to study candesartan cilexetil (TCV-116) membrane interactions. Comparative study with the $\mathrm{AT}_{1} \mathrm{R}$ antagonist drug olmesartan. BBA-Bioenergetics 2014, 1838, 2439-2450.

109. Zervou, M.; Cournia, Z.; Potamitis, C.; Patargias, G.; Durdagi, S.; Grdadolnik, S.G.; Mavromoustakos, T. Insights into the molecular basis of action of the $\mathrm{AT}_{1}$ antagonist losartan using a combined NMR spectroscopy and computational approach. BBA-Bioenergetics 2014, 1838, 1031-1046.

110. Stegbauer, J.; Coffman, T.M. New insights into angiotensin receptor actions: From blood pressure to aging. Curr. Opin. Nephrol. Hypertens. 2011, 20, 84-88.

111. Chang, Y.; Wei, W. Angiotensin II in inflammation, immunity and rheumatoid arthritis. Clin. Exp. Immunol. 2014, doi:10.1111/cei.12467.

112. Valero-Esquitino, V.; Lucht, K.; Namsolleck, P.; Monnet-Tschudi, F.; Stubbe, T.; Lucht, F.; Liu, M.; Ebner, F.; Brandt, C.; Danyel, L.A.; et al. Direct angiotensin type 2 receptor $\left(\mathrm{AT}_{2} \mathrm{R}\right)$ stimulation attenuates $\mathrm{T}$-cell and microglia activation and prevents demyelination in experimental autoimmune encephalomyelitis in mice. Clin. Sci. (Lond.) 2015, 128, 95-109.

113. Marion, E.; Song, O.R.; Christophe, T.; Babonneau, J.; Fenistein, D.; Eyer, J.; Letournel, F.; Henrion, D.; Clere, N.; Paille, V.; et al. Mycobacterial toxin induces analgesia in buruli ulcer by targeting the angiotensin pathways. Cell 2014, 157, 1565-1576.

(C) 2015 by the authors; licensee MDPI, Basel, Switzerland. This article is an open access article distributed under the terms and conditions of the Creative Commons Attribution license (http://creativecommons.org/licenses/by/4.0/). 